\title{
CHANGING STATE WATER ALLOCATION LAWS TO PROTECT THE GREAT LAKES
}

\author{
Joseph W. Dellapenna*
}

\section{INTRODUCTION}

The Great Lakes are five of the world's largest freshwater lakes, constituting about 84 percent of the total fresh surface water in North America and about 22 percent of the total fresh surface water on the planet. ${ }^{1}$ Thus the Lakes were long considered an inexhaustible resource. ${ }^{2}$ Today, some would characterize the Lakes as non-renewable resources because less than 1 percent of the Lakes' waters are renewed annually by precipitation. ${ }^{3}$. The Lakes today face serious challenges from pollution, ${ }^{4}$ invasive species, ${ }^{5}$ wetland loss, ${ }^{6}$ climate disruption, ${ }^{7}$ and declining lake levels. ${ }^{8}$ The Lakes

* Professor of Law, Villanova Univ.; B.B.A., Univ. of Mich. (1965); J.D., Detroit College of Law (1968); LL.M. in International and Comparative Law, George Washington Univ. (1969); LL.M. in Environmental Law, Columbia Univ. (1974). Professor Dellapenna served as Rapporteur of the Water Resources Committee of the International Law Association, leading the drafting of the Berlin Rules on Water Resources (2004), and is Director of the Model Water Code Project of the American Society of Civil Engineers, in which role he led the drafting of the Regulated Riparian Model Water Code (ASCE Standard 40-3) and the Appropriative Rights Model Water Code (2004).

1. Great Lakes: Basic Information, ENVTL. Prot. AGENCY, http://epa.gov/greatlakes/ basicinfo.html (last updated July 5, 2012, archived at http://perma.cc/0Df5xFJNyJ4).

2. Joseph W. Dellapenna, The Interstate Struggles over Rivers: The Southeastern States and the Struggle Over the Hooch, 12 N.Y.U. ENVTL. L.J. 828, 850-51 (2005) [hereinafter Dellapenna, Interstate Struggles].

3. Stanley Changnon, Understanding the Physical Setting: The Great Lakes Climate and Lake Level Fluctuations, in THE LAKE MiCHIGAN WITHDRAWAL AT CHICAGO AND URBAN Drought 39 (Stanley Changnon ed., 1994).

4. See, e.g., Kenneth Kilbert, Tiffany Tisler, \& M. Zack Hohl, Legal Tools for Reducing Harmful Algal Blooms in Lake Erie, 44 U. TOL. L. REV. 69 (2012).

5. See, e.g., Andrew S. Leung, Note, The Adverse Effects of Aquatic Invasive Species on Native and Commercial Fisheries of the Great Lakes and the Exacerbation of the Problem by Judicial Reluctance to Act, 4 KY. J. Equine, AGRIC. \& NAT. REsOURCES L. 525 (2011).

6. See Grace Wever \& Paul Tippett, New Directions for Great Lakes Management: The Vision of the Council of Great Lakes Industries, 26 U. ToL. L. REV. 271, 276-77 (1995).

7. See generally Climate Change and Water: International Perspectives on Mitigation and Adaptation (Joel Smith, Jim Henderson, \& Carol Howe eds., 2009); Peter Gleick et al., Climate Change and the Global Water Crisis: What Businesses NeED to KNow and Do (2009); Claire S. Bleser \& Kristen C. Nelson, Climate Change and Water Governance: An International Joint Commission Case Study, 13 WATER POL'Y 877 (2011); Joseph W. Dellapenna, Climate Disruption, the Washington Consensus, and Water Law Reform, 81 TEMPLE L.Q. 383 (2008) [hereinafter Dellapenna, Washington Consensus]; Joseph W. Dellapenna, Global Climate Disruption and Water Law Reform, 15 WIDENER L. REV. 409 (2010) [hereinafter Dellapenna, Water Law Reform]. 
have gone through cycles of rising and lowering in the past, making it too early to know whether permanently lower levels are coming. ${ }^{9}$ Laws can contribute, for good or ill, to addressing these problems in many ways. The Great Lakes states' legal regimes for allocating surface water to particular uses could facilitate or impede the export of water from the Lakes. State water allocation laws could also enable better adaptation to climate disruption, ${ }^{10}$ but are only tangentially relevant to the other problems above.

Parts of nine states are within the Great Lakes-St. Lawrence watershed: Illinois, Indiana, Michigan, Minnesota, New York, Ohio, Pennsylvania, Vermont, and Wisconsin. Congress has defined eight of these states (excepting Vermont) as "Great Lakes states" for purposes of managing the watershed of the Lakes." Sixty years ago, all eight states were firmly committed to traditional riparian rights for the allocation of water to particular uses. ${ }^{12}$ At that time, the only large-scale withdrawal out of the watershed was the Chicago Sanitary and Shipping Canal, which was limited as a result of interstate litigation in the early decades of the twentieth century. ${ }^{13}$ Today, a concern about proposals to export water from the Great Lakes looms large in the eight states, a concern that emerged from proposals to divert water from Lake Michigan to recharge the Ogallala Aquifer, which stretches across the Great Plains. ${ }^{14}$ While this proposal was effectively blocked by federal legislation, ${ }^{15}$ it led to legal steps to prohibit

8. See, e.g., Cynthia E. Sellinger et al., Recent Water Level Declines in the Lake Michigan-Huron System, 42 ENVT. SCl. TECH. 367 (2008); see also Cynthia Dizikes, As Lake Levels Decline, Worries, Woes Deepen, Boaters, Anglers Struggle with New Headaches, and Fears Grow over Future of Crucial Resource, CHI. TRIB., Oct. 19, 2012, at 1; John Schwartz, Water Levels Fall in Great Lakes, Taking a Toll on Shipping, N.Y. TIMES, June 11, 2013, at A10.

9. Jack Spencer, Defining "Lowest Ever": Exaggeration of Water Levels in the Great Lakes Has Gone Far Enough, THE PIONEer, Feb. 5, 2013, at 4a.

10. See Dellapenna, Washington Consensus, supra note 8; Dellapenna, Water Law Reform, supra note 8.

11. 42 U.S.C. $\S 1962 \mathrm{~d}-20$ (c) (2013). Vermont apparently is omitted from this list because it doesn't touch any of the Great Lakes, but Lake Champlain drains into the St. Lawrence River, so part of the state is within the overall watershed. The overall watershed also includes the provinces of Ontario and Québec, but only Ontario touches the Great Lakes, although the same statute gives certain privileges to Québec as well as Ontario without apparently recognizing the anomaly of privileging Québec while excluding Vermont. Id. $\S 1962 \mathrm{~d}-20 \mathrm{~d}(\mathrm{~b})(2)$. This Article does not consider the law of water allocation in Ontario and Québec.

12. See generally Joseph W. Dellapenna, The Right to Consume Water under "Pure" Riparian Rights, in WATERS AND WATER RIGHTS ch. 7 (Amy K. Kelly ed., 3d ed. 2012) [hereinafter Dellapenna, Right to Consume].

13. See Wisconsin v. Illinois, 281 U.S. 179 (1930), 289 U.S. 395 (1933).

14. J.W. Bulkley, S.J. Wright \& D. Wright, Preliminary Study of the Withdrawal of 10,000 cfs. from Lake Superior to the Missouri River Watershed, 68 J. HYDROLOGY 461 (1983); Kenneth Sheets, War over Water Crisis of the 80s, U.S. NEWs \& WORLD REP., Oct. 31,1983 , at 57 .

15. The Water Resources Development Act of 1986, 42 U.S.C. § 1962d-20 (2013); 
such exports. Partly as a result of these concerns, the eight states have also entered into a new interstate compact, the major focus of which is to bar the export of water out of the watershed. ${ }^{16}$

With less general notice, the eight states also introduced changes in their water laws. In five of the states, comprehensive changes were introduced covering all waters within the state: Wisconsin (1957); ${ }^{17}$ Minnesota (1973); ${ }^{18}$ New York (1979); ${ }^{19}$ Ohio (1988); ${ }^{20}$ and Michigan $(2005) .^{21}$ These comprehensive changes are versions of the new form of water law known as regulated riparianism. ${ }^{22}$ In the other three states, there have been smaller changes in water allocation law, some limited to the waters within the Great Lakes watershed. To some extent, these state laws were overtaken by the Great Lakes-St. Lawrence Basin Compact, which in turn led to the enactment of new laws applicable to the parts of each participating state within the Great Lakes watershed. ${ }^{23}$

Most, if not all, of the legal changes were made in the hope that the new regime would more effectively preclude or at least mostly prevent the export of water from the Great Lakes watershed. In this Article, I briefly outline the water law regimes generally throughout the United States and for each state, with a particular view towards the regime's effectiveness at limiting or precluding water exports from the Great Lakes watershed. I begin with the extent to which common law doctrines relating to water usage served to limit the export of water from the Lakes-namely, riparian rights, regulated riparianism, and the public trust doctrine. Then I explore the statutes enacted in most Great Lakes states in the 1980s to block the export of water from the Lakes. Finally, I explore the statutes enacted after 2008 to implement the Great Lakes-St. Lawrence River Water Resources Compact. I do not discuss the interstate compact, which I have analyzed

Dellapenna, Interstate Struggles, supra note 3, at 859-64; Jerome Hinkle, Troubled Waters: Policy and Action in the Great Lakes, 20 T.M. CoOLEY L. REV. 281, 310-14 (2003).

16. Great Lakes Watershed Water Resources Compact, Pub. L. 110-342, 122 Stat. 3740, $\S \S 4.8-4.9,4.11$ (2008). Ontario and Québec were invited to, and did join, an analogous, non-binding international agreement. Great Lakes-St. Lawrence River Watershed Sustainable Water Agreement, arts. 201-203 [hereinafter Agreement], archived at http://perma.cc/0tJkKiDkeot. Vermont was not invited to join the compact or the agreement. The two instruments are analyzed in Joseph W. Dellapenna, Regulated Riparianism, in WATERS AND WATER Rights, § 9.06(C)(2), §§ 9-244-9-247 (Amy K. Kelly ed., 3d ed. 2012) [hereinafter Dellapenna, Regulated Riparianism].

17. WIS. STAT. $\S \S 30.18,30.28,30.292-30.298,281.35$ (2011-12).

18. MINN. STAT. $\$ \S 103 G .00-103 G .315$ (2013) (current version).

19. N.Y. ENVTL. CONSERV. LAW $\S \S 15-0101-15-3301$ (2013) (current version).

20. OHIO REV. CoDE ANN. $\S \S 1501.30-1501.35$ (2013) (current version).

21. MicH. COMP. LAWS $\$ \S 324.32701-324.32803$ (2013) (current version).

22. See generally Dellapenna, Regulated Riparianism, supra note 17.

23. Great Lakes Water Resources Compact and Agreement, ALLIANCE FOR THE GREAT LAKES, http://www.greatlakes.org/Page.aspx?pid=1330\& frcrld=1 (last visited Nov. 11, 2013, archived at http:/www.perma.cc/0MTqsaEE9LS). 
elsewhere, ${ }^{24}$ or the International Joint Commission between Canada and the United States, which I have also analyzed elsewhere. ${ }^{25}$

\section{A BRIEF OVERVIEW OF WATER ALlOCATION LAW: PROPERTY IN WATER}

In the United States and other countries water usually is allocated through legal recognition of a private property right to the use of water. The paradigm of property in the common law remains the fee simple absolute. Even today, land can be demarcated and considered, for most purposes, as exclusively belonging to a particular owner with little regard for the effects on other persons or their property despite the law of nuisance and the law of zoning. ${ }^{26}$ Land, however, more or less stays put within its boundaries. Flowing water, in contrast, is constantly in motion and simply does not fit very easily into such a legal paradigm. Not only does water move, but it is used and reused continually as it moves through the hydrological cycle. ${ }^{27}$ There is considerable debate about what is the best form of property rights for water in its natural condition. ${ }^{28}$ Private property in water, like all private property rights, can be broadly divided into one of three types of property: common property; private property; and public property. ${ }^{29}$

24. See generally id. at 9-244-9-247; Joseph W. Dellapenna, International Law's Lessons for the Law of the Lakes, 40 U. MICH. J.L. REFORM 747, 781-87 (2007).

25. See generally Dellapenna, Regulated Riparianism, supra note 17; Joseph W. Dellapenna, Canadian International Waters, in WATERS AND WATER RIGHTS ch. 50 (Amy K. Kelly ed., 3d ed. 2012).

26. See generally Henry E. Smith, Property as the Law of Things, 125 HARV. L. REv. 1691 (2012).

27. See Samuel C. Wiel, Natural Communism: Air, Water, Oil, Sea, and Seashore, 47 HARV. L. REv. 425 (1934). For more recent studies, see Eric R. Claeys, Exclusion and Private Law Theory: A Comment on Property as the Law of Things, 125 HARV. L. REV. ForUm 133, 140-42 (2012); Henry E. Smith, Governing Water: The Semicommons of Fluid Property Rights, 50 ARIZ. L. REV. 445 (2008).

28. See, e.g., R.R. BOWKER, INTRODUCTION TO THE ECONOMICS OF WATER RESOURCES: An International Perspective (1998); Terence Richard Lee, Water MaNagement For the 2lst Century: The Allocation Imperative 53-87 (1999); Nigel Bankes, Policy Proposals for Reviewing Alberta's Water (Re)Allocation System, 20 J. ENVTL. L. \& PRAC. 81 (2010); J.B. Ruhl \& James Salzman, The Law and Policy Beginnings of Ecosystem Services, 22 J. LAND USE \& ENVTL. L. 157 (2007); Adam Schempp, Western Water Law in the 21st Century: Policies and Programs that Stretch Supplies in a Prior Appropriation World, 40 ENVTL. L. RPTR. 10394 (2010); Kevin M. Sibbernsen, Looking for Water Down Under: Revitalizing Wyoming's Water Law in Light of New South Wales's Water Management Act 2000, 21 Geo. INT'L ENVTL. L. ReV. 761 (2009).

29. See Harold Demsetz, Toward a Theory of Property, 57 AM. Econ. Rev. 347 (1968); see also JOHN HART Ely, JR., ProperTy RIGHTS IN AMERICAN HISTORY (1997); William L. Cloran, The Ownership of Water in Oregon: Public Property v. Private Commodity, 47 Willamette L. Rev. 627 (2011); Dellapenna, Washington Consensus, supra note 8; Dellapenna, Water Law Reform, supra note 8; Amnon Lehavi, Mixing Property, 38 SETON 
In the United States, water allocation law remains, for the most part, state law. The three models of private property law-common property, private property, and public property - each corresponds to one of the three real-world forms of water law found in the several United States today. ${ }^{30}$ Work on the theory of private property suggests that the correspondence of the forms of water law to the theoretical models allows us to predict with some certainty whether existing forms are adaptable to changing circumstances, or whether an entirely new form must be substituted when water demand or supply change dramatically. ${ }^{31}$

To the east of Kansas City, water was readily available to people at little or no cost. ${ }^{32}$ Although there might be serious problems with water quality, shortages, historically, were rare and short-lived. ${ }^{33}$ There evolved in this setting a body of law known as riparian rights, predicated on treating the resource as common property ${ }^{34}$ To the west of Kansas City, water often was scarce, or at least misplaced. ${ }^{35}$ There, the right to use water was treated as private property under the law of appropriative rights. ${ }^{36}$ Finally, in the second half of the twentieth century, water users in the eastern United States began to experience recurring and intensifying shortages. ${ }^{37} \mathrm{~A}$ bit more than half of the states that had been applying riparian rights responded by developing a third model known as regulated riparianism, which treats

HALl L. REV. 137 (2008); Smith, supra note 27; Philip J. Weiser \& Dale Hatfield, Spectrum Policy Reform and the Next Frontier of Property Rights, 15 Geo. Mason L. REv. 549 (2008); Sandra B. Zellmer \& Jessica Harder, Unbundling Property in Water, 59 ALA. L. REV. 679 (2008). An ambitious study of the evolution of the common law of water from 1066 to the present posited that there are two forms of property in water, one based on the ownership of land (riparian rights), and the other on the protection of uses (appropriative rights). Anthony Scott \& Georgina Coustalin, The Evolution of Water Rights, 35 NAT. RESOURCES J. 821 (1995). This analysis overlooks the possibility of the public management that is emerging in regulated riparian states. See Dellapenna, Regulated Riparianism, supra note 17.

30. This correspondence was virtually recognized in Keys v. Romley (discussing the three forms of law governing the drainage of diffused surface water, identifying one as a "property regime," one as a "tort regime," and not categorizing the third). Keys v. Romley, 412 P.2d 529 (Cal. 1966).

31. See generally Dellapenna, Water Law Reform, supra note 8.

32. Joseph W. Dellapenna, The Law of Water Allocation in the Southeastern States at the Opening of the Twenty-First Century, 25 U. ARK. LitTle RocK L. REv. 9, 9 (2002) [hereinafter Dellapenna, Allocation in the Southeastern States].

33. Id.

34. See generally Dellapenna, Right to Consume, supra note 13.

35. Dellapenna, Allocation in the Southeastern States, supra note 33.

36. See generally WATERS AND WATER RIGHTS, supra note 13, at chs. 11-17.

37. See, e.g., Tom Avril \& Edward Colimore, The Drought and How We Got There: Lack of Rain a Factor; So Is Poor Planning, Phlla. InQUIRER, Apr. 14, 2002, at A1; Dellapenna, Interstate Struggles, supra note 3; Lesley-Ann Dupigny-Giroux, Towards Characterizing and Planning for Drought in Vermont, 37 J. AM. WATER RES. Ass'N 505 (2001); Kenneth S. Gould, An Introduction to Water Rights in the Twenty-First Century: The Challenges Move East, 25 U. ARK. LITTLE Rock L. ReV. 3 (2002). 
water as public property. ${ }^{38}$

I have written extensively on each type of property in water and water usage elsewhere. ${ }^{39}$ In this paper, I will only examine how the Great Lakes states have sought to use water allocation law as a device for impeding or precluding the export of waters from the Great Lakes-St. Lawrence Watershed. I will also examine a different kind of proprietary interest that arises under the rubric of the public trust doctrine and how it might be used in attempts to preclude the export of water from the Lakes.

\section{TRADITIONAL RIPARIAN RIGHTS AS LIMITING THE EXPORT OF WATER}

Having written elsewhere about the law of riparian rights, ${ }^{40}$ I do not present a full analysis here. Instead, I explore those aspects of riparian rights that are relevant to the export of water from the watershed of origin. Three features of traditional riparian rights would preclude the export of water from a watershed: the natural flow theory, the limitation of water use to riparian land, and the watershed rule. The natural flow theory effectively disappeared in the late nineteenth century, if it ever actually applied to water users, while the riparian land requirement and the watershed rule both were seriously eroded in the late twentieth and early twenty-first centuries. As a result, even without considering the possibility that a state might choose to override riparian rights to authorize exports by statute, the common law of riparian rights is no longer an effective barrier to the export of water from the Great Lakes Watershed.

\section{A. The Natural Flow Theory}

The earliest cases announcing the theory of riparian rights often stated that riparian landowners have the right to have water flow across, or lie upon, their land in its natural condition, without alteration by others of the rate of flow, the quantity, or the quality of the water. ${ }^{41}$ Such language

38. See generally Dellapenna, Regulated Riparianism, supra note 17.

39. See Joseph W. Dellapenna, Adapting Riparian Rights to the Twenty-First Century, 106 W. VA. L. REV. 539, 563-64 (2004) [hereinafter Dellapenna, Adapting Riparian Rights]; Joseph W. Dellapenna, Developing a Suitable Water Allocation Law for Pennsylvania, 17 VILLA. ENVTL. L.J. 1, 19-21 (2006), archived at http://perma.cc/0og2SJwmEbe [hereinafter Dellapenna, Water Allocation Law]; Dellapenna, Washington Consensus, supra note 8; Dellapenna, Water Law Reform, supra note 8.

40. See generally Dellapenna, Right to Consume, supra note 13.

41. Such language appears in the very first precedent for riparian rights anywhere in the common law world. Merritt v. Parker, 1 N.J.L. 529, 530 (Sup. Ct. 1795); see also Tyler v. Wilkinson, 24 F. Cas. 472, 474 (D.R.I. 1827); Pennsylvania R.R. v. Miller, 3 A. 780 (Pa. 1886); see generally Joseph W. Dellapenna, The Evolution of Riparianism in the United States, 95 MARQ. L. REV. 53, 64-66 (2011) [hereinafter Dellapenna, Evolution of Riparianism], archived at http://perma.cc/0HskU5FCiUt. 
continues to show up in cases today. ${ }^{42}$ If that were truly the law of riparian rights, it would effectively preclude any export of water from the Great Lakes-St. Lawrence Watershed because such an export would necessarily alter the natural flow. Thus, in theory, any person owning riparian land within the watershed could sue to enjoin a withdrawal of water out of the watershed without proof of injury. ${ }^{43}$ Such a restrictive reading was probably never in fact the law under riparian rights, ${ }^{44}$ except when the natural flow theory was occasionally invoked to compel a public entity, such as a municipality, to pay just compensation for displacing existing riparian uses. ${ }^{45}$ Even if the natural flow theory was once the correct understanding of riparian rights, courts invariably have abandoned it whenever it threatened to prevent the development and use of the water resources of a state. $^{46}$

\section{B. Use on Non-Riparian Land}

While western states abandoned riparian rights in favor of appropriative rights, ${ }^{47}$ eastern states (including the states sharing the Great Lakes-St. Lawrence Watershed) all adopted the reasonable use rule for riparian rights. ${ }^{48}$ The reasonable use theory made the outcome of litigation between competing water users both unpredictable and unstable because courts used a balancing test to allocate water to the use that best served society's interests. ${ }^{49}$ Nevertheless, the reasonable use theory, if strictly

42. See, e.g., Mich. Citizens for Water Conservation v. Nestlé Waters N. Am., Inc., 709 N.W.2d 174, 194 (Mich. App. 2005), rev'd on other grounds, 737 N.W.2d 447 (Mich. 2007); Browning v. Halle, 632 S.E.2d 29 (W. Va. 2005) (dictum).

43. See, e.g., Ulbricht v. Eufala Water Co., 6 So. 78 (Ala. 1889); Scott v. Fruit Growers' Supply Co., 258 P. 1095 (Cal. 1927); Robertson v. Arnold, 186 S.E. 806 (Ga. 1936); Woody v. Durham, 267 S.W.2d 219 (Tex. Civ. App. 1954), writ ref'd, n.r.e.

44. See generally Dellapenna, Right to Consume, supra note 13 , at $\$ 7.02$ (c).

45. See, e.g., G\&A Contractors, Inc. v. Alaska Greenhouses, Inc., 517 P.2d 1379, 138485 (Alaska 1974); Dimmock v. City of New London, 245 A.2d 569, 572-74 (Conn. 1968).

46. This was true even in the earliest cases involving riparian rights. See Mason v. Hoyle, 14 A. 786 (Conn. 1888); Heath v. Williams, 25 Me. 209 (1845); Pratt v. Lamson, 84 Mass. (2 Allen) 275 (1861); Red River Rolling Mills v. Wright, 15 N.W. 167 (Minn. 1883); Hayes v. Waldron, 44 N.H. 580 (1863); Farrell v. Richards, 30 N.J. Eq. 511 (1879); Palmer v. Mulligan, 3 Cai. 307 (N.Y. Sup. Ct. 1805); Cooper v. Hall, 5 Ohio 320 (1832); Howell v. McCoy, 3 Rawle 256 (Pa. 1832); Richmond Mfg. Co. v. Atlantic De-Laine Co., 10 R.I. 106 (1871); see generally Dellapenna, Evolution of Riparianism, supra note 42, at 66-75.

47. The history of the development and spread of appropriative rights across the west is detailed in Joseph W. Dellapenna, Dual Systems, in WATERS AND WATER RIGHTS, supra note 12 , at $\S \S 8.02-8.02$ (c) [hereinafter Dellapenna, Dual Systems]; Dellapenna, Evolution of Riparianism, supra note 42 , at 75-81.

48. Dellapenna, Right to Consume, supra note 13, at $\S 7.01(\mathrm{~b})$.

49. See Dellapenna, Water Law Reform, supra note 8, at 423-25; see generally Dellapenna, Right to Consume, supra note 13, at $\S \S 7.03-7.03(\mathrm{e})$; RESTATEMENT (SECOND) OF TORTS § 850A (1979). 
applied, would preclude the export of water from a watershed, including the Great Lakes Watershed, because the right to use water is limited to uses on riparian land-land that is contiguous to the source of the water. ${ }^{50}$

If a tract of land on which water is to be used is separated from the water source, no matter how narrow the intervening land, that tract of land is non-riparian. ${ }^{51}$ Unlike the balancing approach to disputes between competing riparian landowners, a riparian landowner has the right to enjoin a non-riparian's use because non-riparians' uses are inherently unreasonable, and, therefore, are not to be balanced against riparian uses. ${ }^{52}$ A minor twist in this context would arise depending on whether the state in which the tract was located followed the "unity of title" test or the "source of title" test in defining riparian tracts. ${ }^{53}$ Under the "source of title" test, subdivision of a tract of land terminates the riparian status of any part no longer adjacent to the water source, and the affected parts do not recover their riparian status even if reunited with riparian land under a single ownership. ${ }^{54}$ This can only be determined through a title search. Under the

50. City of Orange Beach v. Benjamin, 821 So. 2d 193, 195 (Ala. 2001); California Farm Bureau Fed'n v. State Water Res. Control Bd., 247 P.3d 112, 118 n.7 (Cal. 2011); City of Waterbury v. Town of Washington, 800 A.2d 1102, 1149 (Conn. 2002); Kranz v. Meyers Subdivision Prop. Owners' Ass'n, 969 N.E.2d 1068, 1071 n.2, 1079 (Ind. Ct. App. 2012); Conrad/Dommel, LLC v. W. Dev. Co., 815 A.2d 828, 845 (Md. Spec. Ct. App. 2003); 2000 Baum Family Trust v. Babel, 793 N.W.2d 633 (Mich. 2010); Sec'y of State v. Gunn, 75 So. 3d 1015, 1018 n.7 (Miss. 2011); Edmondson v. Edwards, 111 S.W.3d 906, 909 (Mo. Ct. App. 2003); Koch v. Aupperle, 737 N.W.2d 869, 878 (Neb. 2007), appeal after remand on other grounds, 763 N.W.2d 415 (Neb. 2009); Panetta v. Equity One, Inc., 920 A.2d 638, 644 (N.J. 2007); Thury v. Britannia Acquisition Corp., 738 N.Y.S.2d 82 (2002); Inland Harbor Homeowners Ass'n v. St. Joseph's Marina, LLC, 724 S.E.2d 92, 97 (N.C. Ct. App. 2012); Portage Cnty. Bd. of Comm'rs v. City of Akron, 808 N.E.2d 444, 455 (Ohio Ct. App. 2004), rev'd on other grounds, 846 N.E.2d 478 (Ohio 2006); Brainard v. State, 12 S.W.3d 6, 15 n.2 (Tex. 1999); In re Flood Litigation, 607 S.E.2d 863, 875 (W. Va. 2004), after remand, 668 S.E.2d 203 (W. Va. 2008); Wendt v. Blazek, 626 N.W.2d 78, 81 (Wis. Ct. App. 2001), rev. denied, 630 N.W.2d 221 (Wis. 2001); see also Virginia v. Maryland, 540 U.S. 56 (2003); RESTATEMENT (SECOND) OF TORTS $\$ 853$ (1979).

51. City of Orange Beach v. Benjamin, 821 So. 2d 193, 196 (Ala. 2001); Krieger v. Town of Longboat Key, 849 So. 2d 358 (Fla. Dist. Ct. App. 2003); Ponderosa Home Site Lot Owners v. Garfield Bay Resort, Inc., 85 P.3d 675, 678 (Idaho 2004); Gregg Neck Yacht Club, Inc. v. Cnty. Comm'rs., 769 A.2d 982 (Md. Ct. Spec. App. 2001); 2000 Baum Family Trust, 773 N.W.2d at 54-56, rev'd on other grounds, 793 N.W.2d 633 (Mich. 2010); Miller v. Powers, 862 N.Y.S.2d 242 (App. Div. 2008); Shaheen v. Cnty. of Mathews, 579 S.E.2d 162 (Va. 2003).

52. The leading case is Stratton v. Mount Hermon Boys' Sch., 103 N.E. 87, 88 (Mass. 1913). See also Anderson v. Bell, 433 So. 2d 1202 (Fla. 1983); Kennebunk, Kennebunkport and Wells Water Dist. v. Maine Tpk. Auth., 71 A.2d 520 (Me. 1950); Mich. Citizens for Water Conservation v. Nestlé Waters N. Am., Inc., 709 N.W.2d 174, 196, 204 (Mich. Ct. App. 2005), rev'd on other grounds, 737 N.W.2d 447 (Mich. 2007).

53. See Dellapenna, Right to Consume, supra note 13, at $\S 7.02(\mathrm{a})(2)$.

54. Pleasant Valley Canal Co. v. Borror, 72 Cal. Rptr. 2d 1, 23-24 (Cal. Ct. App. 1998) (dictum); Williams v. Rankin, 54 Cal. Rptr. 184 (Cal. Ct. App. 1966); Wasserburger v. 
"unity of title" test, an entire tract of land under single ownership is considered riparian if any part of the tract is riparian, regardless of ownership history. ${ }^{55}$ Strict application of the rule on non-riparian uses by itself would effectively preclude all but de minimus exports from the watershed, regardless of which approach was used to define riparian land, for few, if any, tracts of land would extend very far beyond the boundaries of the watershed.

Growing demand for water put pressure on the rule limiting uses to riparian lands. The desire to evade the limitation of uses to riparian lands was prominent in the first case to announce the Colorado rule of pure appropriative rights (without any vestige of riparian rights). ${ }^{56}$ As demand for water grew in states that continued to adhere to riparian rights, critics began to identify this feature of riparian rights as one of its major defects: there is, after all, no reason to think that the most socially or economically desirable uses of water would be on riparian land. ${ }^{57}$

The American Law Institute included several provisions in the Restatement (Second) of Torts that would broaden the range of uses recognized and protected under riparian rights. The Restatement (Second) of Torts would allow riparian owners to make non-riparian uses of the water withdrawn from a water body. ${ }^{58}$ This change expresses the notion that riparian rights exist for the benefit of the owner of the rights, rather than the more traditional notion that riparian rights were a function of the relationship of the land to the water (a benefit, if you will, to the land). ${ }^{59}$ The Restatement (Second) of Torts proposed even more far-reaching changes proposed for the rights of users who are in no way riparian, converting a non-riparian's use into a "privilege ... subject to defeasance by the exercise of riparian rights. ${ }^{160}$ This is the situation in dual-system states where non-riparians use the water pursuant to an appropriation

Coffee, 141 N.W.2d 738 (Neb. 1996), modified on other grounds, 144 N.W.2d 209 (Neb. 1966); Watkins Land Co. v. Clements, 86 S.W. 733 (Tex. 1905); Yearsley v. Cater, 270 P. 804 (Wash. 1928).

55. Phelps v. State Water Res. Control Bd., 68 Cal. Rptr. 3d 350, 373-74 (Cal. Ct. App. 2007), rev. denied.

56. Coffin v. Left Hand Ditch Co., 6 Colo. 443 (1882).

57. See, e.g., M. Mason Gaffney, Economic Aspects of Water Resources Policy, 28 AM. J. ECON. \& Sociology 131, 137-38 (1968); see also Michael A. Wehrkamp, Groundwater Allocation in Ohio: The Case for Regulated Riparianism and Its Likely Consequences under McNamara, 40 U. TOL. L. REV. 525, 537 n. 128 (2009).

58. RESTATEMENT (SECOND) OF TORTS $\S 855$ (1979). The Restatement relied on a handful of old cases. Elliott v. Fitchburg R.R. Co., 10 Cush. 191 (Mass. 1852); Harris v. Norfolk \& W. Ry. Co., 69 S.E. 623 (N.C. 1910); and Lawrie v. Silsby, 56 A. 1106 (Vt. 1904). Cases other than Elliott and Harris hold to the contrary. Kennebunk v. Maine Tpk. Auth., 71 A.2d 520 (Me. 1950); Stratton v. Mt. Herman Boys' Sch., 103 N.E. 87 (Mass. 1913); McCord v. Big Bros. Movement, 185 A. 480 (N.J. Ch. 1936); Pernell v. Henderson, 16 S.E.2d 449 (N.C. 1941); Sayles v. City of Mitchell, 245 N.W. 390 (S.D. 1932).

59. RESTATEMENT (SECOND) OF TORTS $\S 855 \mathrm{cmt}$. b. (1979).

60. Id. $\S \S 856 \mathrm{cmt}$. a, 857 . 
permit. The approach would introduce a radical change into the traditional law of riparian rights. Because of this theory, the Restatement (Second) of Torts rejects traditional approaches and treats grantees ${ }^{61}$ and other holders of derivative rights, ${ }^{62}$ as fully riparian, even as against riparians who were strangers to the transaction that created the derivative right. Traditional approaches would hold that derivative rightholders have no rights at all against strangers to the original grant or that derivative rightholders are strictly derivative and could make only such use of the water as the original riparian might have made. ${ }^{63}$

This potentially far-reaching change proposed by the Restatement (Second) of Torts thus far has been embraced only by the Supreme Court of Georgia, in the case of Pyle v. Gilbert. ${ }^{64}$ Pyle involved, inter alia, a dispute about the effect of a conveyance of riparian rights to a non-riparian owner. ${ }^{65}$ The court upheld the conveyance and treated the grantee as if he were a full riparian, reaching this conclusion on the authority of the Restatement without careful consideration of the relevant policies or controlling precedents. ${ }^{66}$

\section{The Watershed Rule}

The classical limitation of uses to riparian lands could aliow de minimus exports from a watershed, but even such small exports are barred under the watershed rule. A watershed is an area of land off of which precipitation runs into a particular water body. ${ }^{67}$ Two sides of a hill or adjacent lands with slight changes in slope lie in different watersheds if the water drains in different directions. ${ }^{68}$ Under the watershed rule, riparian land is defined not only based on contiguity to the water source, but also by being within the same watershed as the water source. ${ }^{69}$ The watershed rule-a vestige of the natural flow theory-allows withdrawals of water from a water source only if the water is returned, directly or indirectly, to the water source of origin. ${ }^{70}$

What constitutes a watershed can be elusive, depending upon the

61. Id. $\S \S 856(2) \mathrm{cmt} . \mathrm{b}, 857(2)$.

62. Id. $\S \S 856(2) \mathrm{cnit}$. c-d.

63. See Dellapenna, Right to Consume, supra note 13, at $\S 7.04$.

64. 265 S.E.2d 584 (Ga. 1980).

65. Id. at 585 .

66. Id. at $588-89$.

67. What is a Watershed?, ENVTL. PROT. AGENCY, http://water.epa.gov/type/watersheds/ whatis.cfm (last updated Mar. 6, 2012, archived at http://perma.cc/0BjfsH7GScm).

68. Ill. ENVTL. PRot. Agency, LAKe Notes: Determining Your LAKE's Watershed 1 (1999), archived at http://perma.cc/0DFC9YrkNvx.

69. Rancho Santa Margarita v. Vail, 81 P.2d 533, 552 (Cal. 1938); Dimmock v. City of New London, 245 A.2d 569, $572-73$ (Conn. 1968).

70. See Dellapenna, Right to Consume, supra note 13, at $\$ 7.02(a)(2)$. 
geography of drainage, the scale of the inquiry, and the reason for determining the limits of the watershed. ${ }^{71}$ Do the Colorado and Gila Rivers in the southwest form a single watershed, or two watersheds? ${ }^{72}$ Are the Allegheny and Monongahela Rivers, which join to form the Ohio River, a single watershed? For consumptive uses of water, whether the court is dealing with one watershed or two depends on whether the dispute involves two landowners, both of whose land lies above the confluence of the two water bodies, or between two landowners, one of whose land lies below the confluence. $^{73}$

Although the watershed rule does not by itself guarantee maintenance of the natural flow, it does tend in that direction. ${ }^{74}$ While the natural flow theory has been discarded nearly everywhere in favor of the reasonable use theory, ${ }^{75}$ some scholars have championed the natural flow theory as protective of instream flows. ${ }^{76}$ Some courts have embraced the watershed rule without considering whether it serves the needs of a state committed to the reasonable use rule. ${ }^{77}$ This is particularly true in western courts that recognize both riparian rights and appropriative rights. The watershed rule tends to diminish the land to which a riparian right applies. ${ }^{78}$

The problem with the watershed rule is that water might not be most economically, socially, or even ecologically useful in its natural watershed. This reality has led several Great Lakes states to question or abandon the rule. Thus Pennsylvania's Commonwealth Court, an intermediate court,

71. See generally Hans Schreier \& Sandra Brown, Scaling Issues in Watershed Assessments, 3 WATER POL'Y 475 (2001).

72. The question was much disputed in Arizona v. California. 373 U.S. 546, 558-61, 567-81 (1963).

73. Rancho Santa Margarita, 81 P.2d 533; Anaheim Union Water Co. v. Fuller, 88 P. 978 (Cal. 1907); Dimmock, 245 A.2d 569; Little Blue Natural Res. Dist. v. Lower Platte N. Natural Res. Dist., 294 N.W.2d 598 (Neb. 1980); Alburger v. Philadelphia Elec. Co., 535 A.2d 729 (Pa. Commw. Ct. 1988); Town of Gordonsville v. Zinn, 106 S.E. 508 (Va. 1921).

74. Anaheim Union Water Co., 88 P. at 980; Stratton v. Mount Hermon Boys' Sch., 103 N.E. 87, 88 (Mass. 1913); Town of Gordonsville, 106 S.E. at 511.

75. See RESTATEMENT (SECOND) OF TORTS $\S 843 \mathrm{cmt}$. d (rejecting the watershed rule), $\S 850 \mathrm{cmt}$. b (rejecting the "natural flow" theory) (1979); see generally Dellapenna, Evolution of Riparianism, supra note 42, at 64-75.

76. See, e.g., Lynda L. Butler, Allocating Consumptive Water Rights in a Riparian Jurisdiction: Defining the Relationship between Public and Private Interests, 47 U. PITT. L. REv. 95, 156-81 (1985); Peter N. Davis, The Riparian Right of Streamflow Protection in the Eastern States, 36 ARK. L. REV. 47 (1982).

77. See, e.g., Town of Gordonsville, 106 S.E. 508; see also Butler, supra note 77, at 111-17 (supporting the watershed limitation).

78. Rancho Santa Margarita, 81 P.2d 533; Clark v. Allaman, 80 P. 571 (Kan. 1905); In re Applications Nos. 2151, etc. of Cent. Neb. Pub. Power \& Irrigation Dist., 268 N.W. 334 (Neb. 1936); Sayles v. City of Mitchell, 245 N.W. 390 (S.D. 1932); Watkins Land Co. v. Clements, 86 S.W. 733 (Tex. 1905); Yearsley v. Cater, 270 P. 804 (Wash. 1928); see generally Dellapenna, Dual Systems, supra note 48, at § 8.03(b)(3). 
rejected the watershed rule absent proof of an actual injury from transferring water out of the watershed. ${ }^{79}$ That would seem to resolve the question, unless the precedent were overturned by the state supreme court, but Pennsylvania's Supreme Court has not reviewed the question thus far. Yet a later panel of the Commonwealth Court endorsed the watershed rule, without proof of actual injury and without really examining the utility of the rule, in Alburger $v$. Philadelphia Electric $\mathrm{Co}^{80}$ The three judges in Alburger each gave a separate opinion on widely varying grounds, so the ultimate import of that decision remains unclear. ${ }^{81}$ The Michigan Supreme Court has perhaps gone the road pioneered in Pennsylvania, declining to apply the watershed rule as an invariable rule, indicating only that "water should generally not be diverted from a watershed." indicate when the general proposition should not apply.

\section{THE INTRODUCTION OF REGULATED RIPARIANISM}

Riparian rights, the traditional law of all the Great Lakes states, started with a set of propositions that, if strictly applied, would have precluded or at least severely limited the possibility of exporting water from the Great Lakes watershed. Later in the twentieth century, these strictures were being undermined even without any state choosing to promote the export of water, whether within the state or to other states. Public opinion in the Great Lakes states was already moving towards a different sort of legal regime before the Ogallala aquifer proposal raised the specter of possible massive exports of water to the High Plains states. ${ }^{83}$

In eastern states, demand for water continues to increase and precipitation patterns have become more erratic, causing recurring water shortages to become more frequent. ${ }^{84}$ There no longer is enough water to satisfy all needs in many eastern states, disputes over water have become

79. Belin v. Dep't of Envt.. Res., 291 A.2d 553 (Pa. Commw. Ct. 1972).

80. 535 A.2d 729 (Pa. Commw. Ct. 1988).

81. See generally id.

82. Anglers of Au Sable, Inc. v. Department Envtl. Qual., 793 N.W.2d 596, 604 (Mich. 2010).

83. See Bulkley, Wright, \& Wright, supra note 15; Sheets, supra note 15.

84. Xiangdong Jiang et al., USGS: Streamflow of 2011-Water Year Summary, USGS (Jan. 2012), http://pubs.usgs.gov/fs/2012/3085/fs2012-3085.pdf (archived at http://perma.cc/0V83vC5G294) - XIANGDONG JIANG ET AL., USGS: Streamflow of 2011Water Year Summary, USGS 3-5 (JAN. 2012); see also SUSAN J. MARKS, AQUA SHOCK (2009); Jonathan Chenoweth, A Re-Assessment of Indicators of National Water Scarcity, 33 WATER INT'L 5 (2008); Stanley A. Changnon \& Nancy E. Westcott, Heavy Rainstorms in Chicago: Increasing Frequency, Altered Impacts, and Future Implications, 38 J. AM. WATER RESOURCES ASS'N 1467 (2002); see generally ALEXANDER BeLL, PEAK WATER: Civilisation and tHe World Water Crisis (2009); Stephen BRICHIERI-Colombi, THE World Water Crisis: The Failures of Resource Management (2009); Peter H. Gleick et al., THE WORLD's WATER, 2012-2013 (2012). 
commonplace, and water users' experiences have become more similar to that of water users in states to the west of Kansas City-where, because water has always been scarce or in the wrong place, the doctrine of appropriative rights (treating water more or less like private property) became entrenched. ${ }^{85}$ The resulting pressure within many eastern states forced them to abandon or modify riparian rights, which had evolved on the assumption of more or less permanent surpluses. Eastern states did not, however, import appropriative rights to solve these problems. ${ }^{86}$ Instead, a bit more than half of these states and Hawaii created a new system of law that is now called "regulated riparianism." 87

All states today have at least some regulatory statutes dealing with limited aspects of water quantity issues. ${ }^{88}$ In states still basically following traditional riparian rights, regulation protects the public interest in water yet plays little part in resolving quantity disputes between direct water users. Such disputes remain subject to traditional riparian rights. Regulated riparianism is a highly regulated system of water administration based on riparian principles that could best be described as a transition to a system of public property. ${ }^{89}$ The transition from extremely limited regulatory intervention to more or less comprehensive regulation often is incremental rather than from a conscious design to revolutionize water rights. Disagreement persists over when to date the emergence of a true regulated riparian system in a particular state, and even today one could debate whether certain states have in fact crossed the boundary from reliance largely on unregulated common law riparian rights to a regulated riparian

85. See generally Dellapenna, Dual Systems, supra note 48.

86. For the reasons that appropriative rights are not likely to be successful if imported into an eastern state. See id. at $\S \S 8.05-8.05(\mathrm{~b})$.

87. See, e.g., City of Waterbury v. Town of Washington, 800 A.2d 1102, 1149 n.44, 1150 n.45, $1155-57$ (Conn. 2002); JosePh L. SAX et al., Legal CONTROL OF WATER RESOURCES 101-18 (4th ed. 2006); Robert W. Adler, Climate Change and the Hegemony of State Water Law, 29 STAN. ENVTL. L.J. 1, 20 (2010); Robert E. Beck, Current Water Issues in Oil and Gas Development and Production: Will Water Control What Energy We Have?, 49 WASHBURN L.J. 423, 450 (2010); David N. Cassuto \& Rômulo S.R. Sampaio, Water Law in the United States and Brazil-Climate Change \& Two Approaches to Emerging Water Poverty, 35 WM. \& MARY ENVTL. L. \& PoL'Y REv. 371, 381-82, 408 (2011); Lincoln L. Davies, East Going West?: The Promise of Assured Supply Statutes in Modern Real Estate Development, 43 J. MarShall L. REV. 319, 345-46, 350-53, 355, 358 (2010). I devised this name nearly 30 years ago. Joseph W. Dellapenna, Owning Water in the Eastern United States, 6 Proc. E. Mineral L. FNDTN. at 1-33-1-34 (1985).

88. Dellapenna, Regulated Riparianism, supra note 17, at $\$ 9.02$.

89. See Dellapenna, Introduction, in WATERS AND WATER RIGHTS, supra note 13 , 6.01(b)(1) [hereinafter Dellapenna, Introduction]. As with eastern states generally, comprehensive regulated riparian systems are found in about half of the Great Lakes states: Michigan, Minnesota, New York, and Wisconsin. Illinois applies regulated riparianism to groundwater. Pennsylvania applies regulated riparianism through two interstate compacts covering about two thirds of the state. 
system.

The name "regulated riparianism" offends those to whom the words "regulate" and "riparian" are polar opposites; it has the virtue of emphasizing both that the administrative permit process proceeds on essentially riparian principles, and that the new system is a regulation ofrather than a taking of-riparian rights. ${ }^{90}$ Little has been written about regulated riparianism, and most of what has been written has seen regulated riparian statutes as minor modifications superimposed on riparian rights. ${ }^{91}$ Others have seen regulated riparian statutes as poorly drafted appropriative rights statutes. ${ }^{92}$ A few commentators (and one court) have realized that regulated riparianism is a truly different model of water law from traditional riparian rights and from appropriative rights. ${ }^{93}$

Because the regulated riparian statutes were enacted over a span of decades and without a standard model to follow, there is considerable variation in detail between the regulated riparian statutes. Nevertheless there is a common core of principles discoverable by examining the actual regulated riparian statutes set forth in the Regulated Riparian Model Water Code approved by the American Society of Civil Engineers. ${ }^{94}$ No state has a system precisely like the one described here, although several come very close. The Riparian Model Water Code and the relevant chapter of the treatise Waters and Water Rights ${ }^{95}$ are the most convenient sources for detailed analysis of the regulated riparian system. I do not fully explore regulated riparianism here, but rather summarize the core features of the system.

The fundamental requirement of regulated riparian statutes, and the fundamental difference from traditional riparian rights, is that, with limited exceptions, water can be withdrawn from a water source only with a permit

90. Dellapenna, Regulated Riparianism, supra note 17, at $\S \S 9.01,9.04($ a).

91. See, e.g., Scott \& Coustalin, supra note 29, at $899-901$ (describing statutory-i.e., regulated riparian-permit systems as hastily enacted and not fitting with other bureaucratic systems in the state or province of enactment, as well as being of little consequence and not robust enough to deal with any true crisis); see also Richard C. Ausness, Water Rights Legislation in the East: A Program for Reform, 24 WM. \& MARY L. REV. 547 (1983); Peter N. Davis, Eastern Water Withdrawal Permit Statutes: Precedents for Missouri, 47 Mo. L. REV. 429 (1982).

92. See, e.g., George William Sherk, Eastern Water Law, 1 NaT. ResourCES \& ENVT. 7 (1986); Frank J. Trelease, A Water Management Law for Arkansas, 6 U. ARK. LITTLE RocK L.J. 369 (1983).

93. See City of Waterbury v. Town of Washington, 800 A.2d 1102, 1149 n.44, 1150 n.45, 1155-57 (Conn. 2002); Beck, supra note 92, at 450; Cassuto \& Sampaio, supra note 92, at 381-82, 408; Davies, supra note 92, at 345-46, 350-53, 355, 358; Dellapenna, Regulated Riparianism, supra note 17.

94. AmERICAN SOC'Y OF CIVIL ENG'Rs, The Regulated RIPARIAN MOdel Water Code (ASCE Std. 40-03) (Joseph W. Dellapenna ed. 2003) [hereinafter MODEL CODE].

95. Dellapenna, Regulated Riparianism, supra note 17. 
from the state within which the withdrawal occurs. ${ }^{96}$ The rights of water users are determined by conditions attached to the permits, not by the riparian location of the use, yet the criteria by which permit applications are judged is whether the use of the water would be "reasonable." water use is "reasonable" is determined by an administrative agency before a use begins, rather than by a court when a dispute arises with another user. ${ }^{98}$ The statutes often contain preferences for certain classes of uses, ${ }^{99}$ while temporal priority has only a strictly limited role in the permit process. ${ }^{100}$ In most states, permits are issued only for a fixed period of time (from three to twenty years, depending on the state). ${ }^{101}$ When a permit expires, the reasonableness of the use can be reexamined.

Regulated riparian statutes also protect the public interest in the waters of the state in new ways, creating mechanisms for long-term planning through other steps. ${ }^{102}$ The administering agency usually has broad discretion to plan for and deal with crises caused by extreme water shortages. ${ }^{103}$ The agency can incorporate permit conditions based on its plans. ${ }^{104}$ The agency also is often authorized to restrict uses should its plans prove inadequate to an actual shortage notwithstanding any inconsistency with a permit. ${ }^{105}$

Regulated riparian permit requirements are based on the state's police power to regulate water withdrawals and use in order to protect the public health, safety, and welfare, and therefore do not require compensation as a taking of property. ${ }^{106}$ Fear of the political (if not the legal) repercussions of

96. Model CODE, supra note 99, §§ 6R-1-01, 7R-1-01; Dellapenna, Regulated Riparianism, supra note 17, $\S$ 9.03(a)-9.03(a)(2), 9.03(a)(5)(A), 9.05-9.05(c).

97. Model CoDE, supra note 99, $\S$ 2R-1-01, 2R-2-20,6R-3-01, 6R-3-02; Dellapenna, Regulated Riparianism, supra note 17, $\S \S 9.03(\mathrm{~b})-9.03(\mathrm{~b})(3)$. Some jurisdictions use the terms "beneficial," "reasonable-beneficial," or "equitable" instead of "reasonable," but define the alternative term according to the traditional riparian criterion of reasonableness. $I d$. at $\$$ 9.03(b)(2).

98. MODEL CODE, supra note 99, §§ 6R-2-01-6R-2-08, 6R-3-02, 6R-3-05; Dellapenna, Regulated Riparianism, supra note 17, §§ 9.03(a)(5)(A), 9.03(b)(1)-9.03(b)(3).

99. MODEL CODE, supra note 99, §§ 6R-1-02, 6R-3-04; Dellapenna, Regulated Riparianism, supra note $17, \S \S 9.03(\mathrm{a})(3), 9.05(\mathrm{c})$.

100. Model CoDE, supra note 99, §§ 6R-1-03, 6R-3-02; Dellapenna, Regulated Riparianism, supra note $17, \S 9.03(\mathrm{~b})(3)$. This, of course, is one of the key differences of regulated riparianism from appropriative rights.

101. MODEL CODE, supra note 99, § 7R-1-02; Dellapenna, Regulated Riparianism, supra note 17, § 9.03(a)(4) (another key difference from appropriative rights).

102. MODEL CODE, supra note 99, §§ 4R-2-01-4R-2-04; Dellapenna, Regulated Riparianism, supra note 17, §9.05(a)-9.05(d).

103. MoDel CODE, supra note 99, $\S$ 7R-3-01- 7R-3-07; Dellapenna, Regulated Riparianism, supra note $16, \S 9.05(\mathrm{~d})$.

104. MODEL CODE, supra note 99, § 7R-1-01.

105. Id. \& 7R-3-01.

106. State v. Braun, 378 A.2d 640 (Del. 1977); Village of Tequesta v. Jupiter Inlet Corp., 
interference with traditional water rights has led many state legislatures to exempt from the permit requirements some uses (usually agricultural) existing when the regulated riparian statute came into effect, ${ }^{107}$ introducing a significant temporal element. Some states instead guarantee existing users an initial permit subject to renewal on the same terms as any other permit, limiting the temporal preference to a single permit cycle. ${ }^{108}$ Existing users who fail to apply for a permit within a short period of time are conclusively presumed to have abandoned any usage rights. ${ }^{109}$

Regulated riparianism does not solve some problems related to both private and public values. Investment security could be a problem if the permit duration is too short, leaving too little time to recover the cost of a project before the permit expires. ${ }^{110}$ Additional uncertainty arises if the administering agency can modify permits to respond to new developments like unforeseen shortages. ${ }^{111}$ In actual operation, however, investment insecurity seems not to have caused actual difficulty. In practice, administering agencies might be too sensitive to the fears of large institutional investors. ${ }^{12}$ The agencies seldom flatly refuse to renew a permit, although new and more stringent conditions are sometimes attached at the time of renewal. Administering agencies also consult with major water users in planning for water emergencies rather than acting on their own.

Regulated riparian statutes usually make no express provision for the transfer of water rights or permits between potential users. ${ }^{13}$ The Regulated Riparian Model Water Code, in numerous sections, charges the administering agency to encourage market transfers of water. ${ }^{114}$ Given the problems with water markets generally, however, a market probably will not develop for the transfer of water rights under regulated riparian permits. ${ }^{115}$ Theoretically, one purpose of the regulated riparian system is to

371 So.2d 663 (Fla.), cert. denied, 444 U.S. 965 (1979); Iowa Natural Res. Council v. Van Zee, 158 N.W.2d 111 (Iowa 1968); Crookston Cattle Co. v. Minnesota Dep't of Natural Res., 300 N.W.2d 769 (Minn. 1980); Omemik v. State, 218 N.W.2d 734 (Wis. 1974); see generally Dellapenna, Regulated Riparianism, supra note $17, \S 9.04($ a).

107. Dellapenna, Regulated Ripaianism, supra note 17, $9.03(\mathrm{a})(3)$.

108. MODEL CODE, supra note 99, § 6R-1-03; Dellapenna, Regulated Riparianism, supra note $17, \S 9.03(\mathrm{~b})(3)$.

109. Cf. United States v. Locke, 471 U.S. 84 (1985) (cutting off mining claims for failure to file a form); In re Deadman Creek Drainage Watershed, 694 P.2d 1071 (Wash. 1985) (cutting off unused riparian rights in favor of appropriative rights).

110. Dellapenna, Regulated Riparianism, supra note $17, \S 9.03(\mathrm{a})(4)$.

111. Id. $\S \S 9.03(\mathrm{~d}), 9.05(\mathrm{~d})$.

112. See, e.g., Alexander Lane, N.J. Too Generous with Water, Critics Say-State Permits for Large Users Rose Last Year, STAR-LEDGER (Newark, NJ), Sept. 28, 2003, at 21.

113. Dellapenna, Regulated Riparianism, supra note 17, §9.03(d).

114. MODEL CODE, supra note 99 , $\S 1$ R-1-07, 7R-2-01-7R-2-04, 7R-3-05, 9R-1-01, 9R$1-02$.

115. See, e.g., Joseph W. Dellapenna, The Importance of Getting Names Right: The Myth of Markets for Water, 25 WM. \& MARY ENVTL. L. \& POL'Y REV. 317 (2000); see also 
enable the administering agencies to force transfers through non-renewal of permits. ${ }^{116}$ In practice, however, agencies free up less water through the renewal process than theory suggests, because agencies prefer to tighten conditions on existing uses rather than to deny renewals outright. ${ }^{17}$ Nonrenewal will remain an infrequent and cumbersome device for freeing up water unless states are willing to create considerable investment insecurity.

While regulated riparianism is not a perfect system, it does appear to be best suited to the cultural, economic, legal, hydrologic, and political settings of eastern states, in particular because it builds upon the traditional riparian rights rather than attempt to abolish them. ${ }^{118}$ The degree of state control over the withdrawal and use of water would enable a state to limit or even preclude the export of water from the Great Lakes basin, should the state so choose. Without consent by Congress, ${ }^{119}$ this might raise questions under the "Dormant Commerce Clause" of unreasonable interference with interstate or international commerce. ${ }^{120}$ In fact, even before the proposed export of water to recharge the Ogallala Aquifer in $1983,{ }^{121}$ three of the eight Great Lakes states had enacted regulated riparian statutes: Wisconsin (1957); ${ }^{122}$ Minnesota (1973); ${ }^{123}$ and New York (1979). ${ }^{124}$ The three statutes vary considerably, with Minnesota's being the most comprehensive and New York's the most limited. None of these statutes addressed the question of exports from the Great Lakes watershed expressly, leaving it to the administering agency's discretion whether to grant a permit for such a use. Ohio followed suit in $1988 .^{125}$

Stephen N. Bretson \& Peter J. Hill, Water Markets as a Tragedy of the Anticommons, 33 WM. \& MARY ENVTL. L. \& POL'Y REV. 723 (2009).

116. MODEL CODE, supra note 99, § 7R-1-02.

117. See Dellapenna, Regulated Riparianism, supra note 17, §9.03(a)(4), at nn.428-32.

118. Dellapenna, Regulated Riparianism, supra note $17, \S 9.03(\mathrm{a})(5)(\mathrm{D})$.

119. Arguably this consent is provided by the Water Resources Development Act of 1986. 42 U.S.C. § 1962d-20 (1986); see also Great Lakes Watershed Water Resources Compact, Pub. L. 110-342, 122 Stat. 3740, §§ 4.8-4.9, 4.11 (2008).

120. See Sporhase v. Nebraska ex rel. Douglas, 458 U.S. 941 (1982); Tarrant Reg'l Water Dist. v. Sevenoaks, 545 F.3d 906 (10th Cir. 2008); City of El Paso v. Reynolds, 563 F. Supp. 379 (D.N.M. 1983), aff'd, 597 F. Supp. 694 (D.N.M. 1984); City of Altus v. Carr, 255 F. Supp. 828 (W.D. Tex. 1966), aff'd mem., 385 U.S. 17 (1966); Ponderosa Ridge LLC. v. Banner Cty., 554 N.W.2d 151, 159-66 (Neb. 1996); see generally Mark S. Davis \& Michael Pappas, Escaping the Sporhase Maze: Protecting State Waters within the Commerce Clause, 73 LA. L. REv. 175 (2012); Charles T. DuMars \& Stephen Curtice, Interstate Compacts Establishing State Entitlements to Water: An Essential Part of the Water Planning Process, 64 OKLA. L. REv. 515 (2012); Christine A. Klein, The Dormant Commerce Clause and Water Export: Toward a New Analytical Paradigm, 35 HARV. ENVTL. L. REv. 131 (2011); Mark A. Willingham, The Oklahoma Water Sale Moratorium: How Fear and Misunderstanding Led to an Unconstitutional Law, 12 U. DENV. WATER L. REV. 357 (2009).

121. See Bulkley, Wright \& Wright, supra note 15; Sheets, supra note 15.

122. WIS. STAT. $\S \S 30.18,30.28,30.292-30.298,281.35$ (2011-12).

123. MINN. STAT. $\S \S 103$ G.001-103G.315 (2012).

124. N.Y. ENVTL. CONSERV. LAW §§ 15-1501-15-1529 (2006).

125. OHIO REV. CODE ANN. §§ 1501.30-1501.35 (2009). 
Probably because the regulated riparian statutes addressed public concern over the possible export of water from the Great Lakes watershed only indirectly, the other Great Lakes states did not enact such statutes after 1984. Instead, all of the states except Pennsylvania enacted statutes specifically to protect the waters of the Great Lakes watershed. While these statutes have some features in common with regulated riparian statutes, they were designed more to preclude withdrawals than to regulate them. When Michigan in 2005 became the fifth (and thus far the last) Great Lakes state to enact a general regulated riparian statute, ${ }^{126}$ its statute expressly prohibited exports from the Great Lakes watershed. ${ }^{127}$ Because virtually all of Michigan is within the Great Lakes watershed, this prohibition does not interfere with proposed withdrawals for water uses in the state. I shall return to the Michigan statute later. ${ }^{128}$

\section{THE PUBLIC TRUST DOCTRINE}

Before 1970, the public trust doctrine was an arcane concept on the ownership of the beds of navigable waters, with limited utility for general environmental concerns. ${ }^{129}$ In 1970, Joe Sax published an Article that brought the doctrine into the foreground of environmental thinking. ${ }^{130}$ Now some believe the public trust doctrine is the key to ensuring sound management of water resources generally ${ }^{131}$ and to precluding the export of water from the Great Lakes watershed. ${ }^{132}$ This part analyzes the application

126. Мich. Comp. Laws $\S \S 324.32701-324.32803$. Some of this statutory scheme was enacted in 2001, but the permitting requirements were not enacted until 2005.

127. Id. $\S \S 324.32703,324.32704$.

128. See the text infra at notes $225-30,250-56,285-91$.

129. See Illinois Central RR. v. Illinois, 146 U.S. 387 (1892); see generally Sydney F. Ansbacher, Stop the Beach Renourishment: A Case of Maguffins and Legal Fictions, 35 Nova L. Rev. 587 (2011); Craig Anthony (Tony) Arnold, Legal Castles in the Sand: The Evolution of Property Law, Culture, and Ecology in Coastal Lands, 61 SYR. L. REV. 213 (2011); Margaret E. Peloso \& Margaret R. Caldwell, Dynamic Property Rights: The Public Trust Doctrine and Takings in a Changing Climate, 30 STAN. ENVTL. L.J. 51 (2011).

130. Joseph 'L. Sax, The Public Trust Doctrine in Natural Resource Law: Effective Judicial Intervention, $68 \mathrm{MiCH}$. L. REV. 471 (1970).

131. See, e.g., Hope M. Babcock, The Public Trust Doctrine: What a Tall Tale They Tell, 61 S. CAR. L. REv. 393 (2009); Debra L. Donohue, Trampling the Public Trust, 37 B.C. EnvTL. AFF. L. ReV. 257 (2010); Sherry A. Enzler, How Law Mattered to the Mono Lake Ecosystem, 35 WM. \& MarY J. ENvTL. L. \& POL'Y 413 (2011); Robin Kundis Craig, Adapting to Climate Change: The Potential Role of State Public Trust Doctrines, 34 VT. L. Rev. 781 (2010); Paul Stanton Kibel, The Public Trust Navigates California's Bay Delta, 51 NAT. ResourCes J. 35 (2011); Michael Pappas, Unnatural Resource Law: Situating Desalination in Coastal Resource and Water Law Doctrine, 86 TulaNe L. REV. 81, 112-34 (2011); Haochen Sun, Toward a New Social-Political Theory of the Public Trust Doctrine, 35 VT. L. ReV. 563 (2011); Barton H. Thompson, jr., Water as a Public Commodity, 95 MARQ. L. REV. 17 (2011).

132. See, e.g., Bertram C. Frey \& Andrew Mutz, The Public Trust in Surface Waterways 
of the public trust doctrine generally, and then it considers its application to appropriative rights, to riparian rights, and to regulated riparianism, concluding with a brief examination of its possible impact on the export of water from the Great Lakes.

\section{A. The Public Trust Generally}

Initially, the public trust doctrine barred state actions relating to public trust lands, even if authorized by legislation, unless the action furthered trust uses or had only minimal effects on such uses. ${ }^{133}$ Although the US Supreme Court decided an important early case on the doctrine, ${ }^{134}$ the contours of the doctrine (including changes if necessary) remain questions of state law. ${ }^{135}$ In the past forty years, state courts and legislatures have expanded the public trust regarding both the purposes of the trust and the properties subject to the trust. States generally extended the public trust to beaches and other lands the use of which is associated with the use of navigable waters. ${ }^{136}$ Starting from navigation and commercial fishing as trust purposes, states have extended trust purposes to any commercially valuable use, ${ }^{137}$ recreation, ${ }^{138}$ the protection of healthy ecosystems, ${ }^{139}$ and

and Submerged Lands of the Great Lakes States, 40 U. MICH. J.L. REFORM 907 (2007); Melissa K. Scanlan, Implementing the Public Trust Doctrine: A Lakeside View into the Trustees' World, 39 ECOLOGY L.Q. 123 (2012).

133. Illinois Cent. R.R. Co. v. Illinois, 146 U.S. 387 (1892); see generally Tom Eichenberg, Sean Bothwell \& Darcy Vaughn, Climate Change and the Public Trust Doctrine: Using an Ancient Doctrine to Adapt to Rising Sea Levels in San Francisco Bay, 3 GoldEN GATE ENVTL. L.J. 243 (2010).

134. Illinois Cent. R.R. Co., 146 U.S. 387.

135. See PPL Montana, LLC. v. Montana, 132 S. Ct. 1215, 1234-35 (2012); Stop the Beach Renourishment, Inc. v. Florida Dep't Envtl. Prot., 130 S. Ct. 2592, 2597-98 (2010); but see Crystal S. Chase, The Illinois Central Public Trust Doctrine and Federal Common Law: An Unconventional View, 16 Hastings W.-Nw. J. ENVTL. L. \& PoL'Y 113 (2010).

136. See generally Dellapenna, Introduction, supra note 95, §6.03(c); Mackenzie S. Keith, Judicial Protection for Beaches and Parks: The Public Trust Doctrine above the High Water Mark, 16 Hastings W.-Nw. J. EnVTL. L. \& PoL'Y 165 (2010); Kenneth K. Kilbert, The Public Trust Doctrine and the Great Lakes Shores, 58 CLEVE. ST. L. REV. 1 (2010). At the opposite extreme, one court apparently rejects all possible extensions of the public trust to additional properties. Bell v. Town of Wells, 557 A.2d 168 (Me. 1989).

137. Approved commercial activities include, among others, drilling for oil, constructing highways, and manufacturing steel. See CWC Fisheries, Inc. v. Bunker, 755 P.2d 1115 (Alaska 1988); State v. Superior Court, 625 P.2d 256 (Cal.), cert. denied sub nom. Tahoe Shorezone Representation v. California, 454 U.S. 865 (1981); In re Water Use Permit Applications, 9 P.3d 409, 449-51 (Haw. 2000) ("economic development"); Committee to Save the Upper Androscoggin v. New Hampshire Water Resources Bd., 466 A.2d 1308 (N.H. 1983); Commonwealth v. Morgan, 303 S.E.2d 899 (Va. 1983); Caminiti v. Boyle, 732 P.2d 989 (Wash. 1987), cert. denied, 484 U.S. 1008 (1988); Lake Beulah Water Mgmt. Dist. v. Sate Dep't Nat. Resources, 799 N.W.2d 73, 84 (Wis. 2011).

138. Often recreation cases involve public access to recreational swimming, boating, or fishing; the application of the public trust to recreational activities has even been used to justify a massive sports stadium complex that included hotels, shopping, and parking 
aesthetic values. ${ }^{140}$ Courts have also extended the public trust to "public waters" overlying public trust lands ${ }^{141}$ and to non-navigable tributaries of navigable waters. ${ }^{142}$ Courts refused to extend the public trust to nonnavigable waters that do not affect navigable waters ${ }^{143}$ or to artificial water bodies. ${ }^{144}$ Whether the public trust extends to groundwater is unsettled. ${ }^{145}$

structures. New Jersey Sports Auth. v. McCrane, 292 A.2d 545 (N.J. 1972), appeal dism'd sub nom. Borough of East Rutherford v. New Jersey Sports Auth., 409 U.S. 943 (1972), on remand sub nom. In re Sports Complex at Hackensack Meadowlands, 62 N.J. 248, 300 A.2d 337, cert. denied, 414 U.S. 989 (1973); see also Metropolitan Sports Facilities Comm'n v. Minnesota Twins Partnership, 638 N.W.2d 214 (Minn. Ct. App. 2002), rev. denied. For more ordinary recreational uses, see Friends of the Parks v. Chicago Park Dist., 786 N.E.2d 161 (Ill. 2002); State v. Haskell, 955 A.2d 737 (Me. 2008); Boston Edison Co. v. Massachusetts Water Resources Bd., 947 N.E.2d 544, 554-57 (Mass. 2011); Montana Trout Unlimited v. Beaverhead Water Co., 255 P.3d 179, 184-85 (Mont. 2011); State v. Bradley, 877 A.2d 601, 606-08 (R.I. 2005); Citizens for Responsible Wildlife Mgmt. v. State, 103 P.3d 203, 205 (Wash. 2004); Lake Beulah Water Mgmt. Dist., 799 N.W.2d 73, 84 (Wis. 2011); see generally Rebecca Abeln, Instream Flows, Recreation as Beneficial Use, and the Public Interest in Colorado Water Law, 8 U. DeNV. WATER L. REV. 517 (2005); Frey \& Mutz, supra note 138; Damon Schmidt, Wiping out the Surfboards on Point Panic, 27 U. Haw. L. REV. 303, 312-19 (2004).

139. National Audubon Soc'y v. Superior Ct., 658 P.2d 709 (Cal. 1983), cert. denied sub nom. City of Los Angeles Dep't of Water \& Power v. National Audubon Soc'y, 464 U.S. 977 (1983); In re Water Use Permit Applications, 9 P.3d 409, 448-51 (Haw. 2000); Citizens for Responsible Wildlife Mgmt. v. State, 103 P.3d 203, $205-06$ (Wash. 2004); see generally Véronique Jarrell-King, Wildlife, Water Quality, and the Public Trust Doctrine: A Means of Enforcing Agricultural Nonpoint Source Pollution Management Plans., 23 VILL. ENVTL. L.J. 1 (2012); Robin Kundis Craig, A Comparative Guide to Western States' Public Trust Doctrines: Public Values, Private Rights, and the Evolution Toward an Ecological Public Trust, 37 ECOLOGY L.Q. 53, 80-92 (2010); Frey \& Mutz, supra note 138, at 951-57; Sharon Megdal, Joanna Nadeau, \& Tiffany Tom, The Forgotten Sector: Arizona Water Law and the Environment, 1 ARIZ. J. ENVTL. L. \& POL'Y 243, 260-65 (2011).

140. National Audubon Soc'y, 658 P.2d 709; Lake Beulah Water Mgmt. Dist., 799 N.W.2d at 84; see generally Frey \& Mutz, supra note 138, at 951, 953.

141. See, e.g., National Audubon Soc'y, 658 P.2d 709; Pratt v. State, 309 N.W.2d 767 (Minn. 1981).

142. National Audubon Soc'y, 658 P.2d at 721; see generally Dellapenna, Introduction, supra note 95, $\S$ 6.02(f); Alexandra B. Klass, Modern Public Trust Principles: Recognizing Rights and Integrating Standards, 82 NOTRE DAME L. REV. 699 (2006).

143. See, e.g., Hi-Desert County Water Dist. v. Blue Skies Country Club, Inc., 28 Cal. Rptr. 2d 909, 916 n.10 (Ct. App. 1994), rev. denied; Golden Feather Cmty. Ass'n v. Thermalito Irrigation Dist., 257 Cal. Rptr. 836, 841-42 (Ct. App. 1989).

144. Golden Feather Cmty. Ass'n, 257 Cal. Rptr. at 842 (Ct. App. 1989).

145. See generally Jordan Browning, Unearthing Subterranean Water Rights: The Environmental Law Foundation's Efforts to Extend the Public Trust Doctrine, 34 ENVIRONS EnVtL. L. \& Pol'y J. 231 (2011); Danielle Spiegel, Stud. Art., Can the Public Trust Doctrine Save Western Groundwater, 18 N.Y.U. ENVL. L.J. 412 (2010); Jack Tuholske, Trusting the Public Trust: Application of the Public Trust Doctrine to Groundwater Resources, 9 VT. J. ENVTL. L. 189 (2008). Ohio amended its constitution in 2008 to bar application of the public trust doctrine to groundwater. Ohio Const. art. $1, \S 19 \mathrm{~b}(\mathrm{E})$. Vermont by statute has extended the public trust to groundwater. VT. STAT. ANN. tit. 10, $\S \S 1390(5), 1418(i)$, tit. $29 \S 401$. 


\section{B. Application of the Public Trust to Appropriative Rights}

Appropriative rights were conceived of as private property without real attention to the public interest. Application of the public trust doctrine to appropriative rights seems to introduce concern for the public interest. ${ }^{146}$ The first case to apply the public trust to appropriative rights was decided in 1976. ${ }^{147}$ That case, however, concerned applications for new appropriations, leaving unclear whether the doctrine could affect appropriations perfected before 1976. ${ }^{148}$ The possibility of such an impact arose in National Audubon Society v. Superior Court ${ }^{149}$ in which California's Supreme Court held that an appropriation permit issued to the City of Los Angeles in 1940 was subject to review and possible invalidation because of the predecessor to the State Water Resources Control Board failed to consider the public trust in the waters in question. Before 1955, the Board had no authority to consider the public trust in reviewing applications for appropriations. ${ }^{150}$ The Board, moreover, had not done so after $1955 .{ }^{151}$ The court remanded National Audubon, directing the Board to reexamine the permit's consistency with the public trust. ${ }^{152}$ The decision theoretically made every California appropriation subject to review and potentially invalid, ${ }^{153}$ briefly producing consternation among California water users, managers, and lawyers. ${ }^{154}$ Today, seven states apply the public trust to appropriative rights

146. See, e.g., John Hart, Storm over Mono: The Mono Lake Battle and the CAlIFORNIA WATER FUTURE (1996), archived at http://perma.cc/0DZmHGACaGr; Craig Anthony (Tony) Arnold, Working out an Environmental Ethic: Anniversary Lessons from Mono Lake, 4 Wyo. L. REv. 1 (2004).

147. United Plainsmen Ass'n v. North Dak. State Water Conserv. Comm'n, 247 N.W.2d 457 (N.D. 1976). For earlier appropriative rights decisions that might be seen as implicating the public trust, see Craig, supra note 145, at 59-61.

148. One commentator even described United Plainsman as "not really a true water rights case." Arthur Littleworth, The Public Trust vs. the Public Interest, 19 PAC. L.J. 1201, 1201 n.3 (1988).

149. National Audubon Soc'y v. Superior Court, 658 P.2d 709 (Cal. 1983), cert. denied sub nom. City of Los Angeles Dep't of Water \& Power v. National Audubon Soc'y, 464 U.S. 977 (1983).

150. National Audubon Soc' $y, 658$ P.2d at 726.

151. Id. at 712 .

152. Id. at 724 .

153. Michael W. Graf, Using the Public Trust Doctrine to Achieve Proportionate Reductions of Water Diversions from the Delta, 13 UCLA J. ENVTL. L. \& POL'Y 263 (1995). Lynda Butler argued that the public trust requires continual monitoring and reappraisal of water usage and thus poses the potential to invalidate appropriative rights even after a permitting authority has considered the public trust in granting a permit. Lynda L. Butler, Environmental Water Rights, 9 VA. ENVTL. L.J. 323, 336 (1990); see also Craig, supra note 145, at 84-86; Richard Roos-Collins, A Plan to Restore the Public Trust Uses of Rivers and Creeks, 83 TEX. L. REv. 1929 (2005).

154. See, e.g., James L. Huffman, Avoiding the Takings Clause through the Myth of Public Rights: The Public Trust and Reserved Rights Doctrines at Work, 3 J. LAND USE \& 
and two states decline to do so. ${ }^{155}$ Even courts that reject application of the public trust to appropriative rights introduced similar policies in other ways. ${ }^{156}$

The public trust doctrine proved not to be the threat that National Audubon seemed to be. On remand, the plaintiffs found themselves before an unsympathetic judge. ${ }^{157}$ The Court of Appeals was more sympathetic. It ordered water to be released for the lake $\mathrm{e}^{158}$ and subsequently denied the city an opportunity to study the needs of the fish. ${ }^{159}$ The public trust doctrine, however, was only a make-weight argument at the end of the two decisions. The court relied on other grounds, ${ }^{160}$ and it eschewed the reasonableness balancing process that the California Supreme Court in National Audubon had told us was at the heart of the public trust doctrine. ${ }^{161}$ The two opinions

ENVTL. L. 171 (1987); Richard J. Lazarus, Changing Conceptions of Property and Sovereignty in Natural Resources: Questioning the Public Trust Doctrine, 71 Iowa L. Rev. 631 (1986).

155. The following cases apply the public trust doctrine to appropriative rights: Nat'l Audubon Soc'y v. Superior Court, 658 P.2d 709 (Cal. 1983), cert. denied sub nom., L.A. Dep't of Water \& Power v. Nat'l Audubon Soc'y, 464 U.S. 977 (1983); Idaho Conservation League v. State, 911 P.2d 748 (Idaho 1995); Mont. Trout Unlimited v. Beaverhead Water Co., 255 P.3d 179, 184-85 (Mont. 2011); N.D. State Water Comm'n v. Bd. of Managers, 332 N.W.2d 254 (N.D. 1983); Parks v. Cooper, 676 N.W.2d 823, 835-39 (S.D. 2004); City of San Marcos v. Tex. Comm'n on Envtl. Quality, 128 S.W.3d 264, 272 (Tex. App. 2004), rev. denied; Colman v. Utah State Land Bd., 795 P.2d 622 (Utah 1990). The following cases decline to apply the public trust doctrine to appropriative rights: People v. Emmert, 597 P.2d 1025 (Colo. 1979); Rettkowski v. Dep't of Ecology, 858 P.2d 232, 239-40 (Wash. 1993). See generally Jeffrey W. Appel, Ability and Responsibility of State Engineer Regarding Reallocation of Water Rights, 20 J. LAND RESOURCES \& ENVTL. L. 41, $51-54$ (2000); Michael C. Blumm \& Erika Doot, Oregon's Public Trust Doctrine: Public Rights in Waters, Wildlife, and Beaches, 42 ENVTL, L. 375 (2012); William F. Cloran, The Ownership of Water in Oregon: Public Property vs. Private Commodity, 47 Willamette L. Rev. 627 (2011); Craig, supra note 145 , at 76-84, 92-197.

156. Colorado's Supreme Court recognizes the state's "fiduciary duty to protect the public," while shying away from the phrase "public trust." Aspen Wilderness Workshop, Inc. v. Colorado Water Conservation Bd., 901 P.2d 1251, 1260 (Colo. 1995). The Washington Supreme Court does not consider the public trust doctrine to be an "independent source of authority" for the Department of Ecology apart from the Water Code. R.D. Merrill Co. v. Pollution Control Hearings Bd., 969 P.2d 458, 467 (Wash. 1999).

157. The attitude of the trial judge is best suggested by his refusal to order the release of sufficient water to sustain fish in the creeks feeding the lake after the California Court of Appeals ordered him to do so; instead he chose to allow the City three years to study how much water should be released. Cal. Trout, Inc, v. Superior Court (California Trout II), 266 Cal. Rptr. 788, 791 (App. 1990).

158. Cal. Trout, Inc. v. State Water Res. Control Bd. (California Trout I), 255 Cal. Rptr. 184 (App. 1989).

159. California Trout II, 266 Cal. Rptr. 788.

160. Id. at 798-802 (relying on the public trust doctrine to deny that primary jurisdiction lay with the State Water Resources Control Board); California Trout I, 255 Cal. Rptr. at 21113 (basing its decision on the grounds that estoppel usually does not apply against the state).

161. Compare Nat'l Audubon Soc'y v. Superior Court, 658 P.2d at 725, with California Trout II, 266 Cal. Rptr. at 796-99, 802-03. 
would stand virtually unchanged without mention of the public trust. ${ }^{162}$

The limited effect of the public trust doctrine explains the ease with which California integrated it into existing institutional arrangements. ${ }^{163}$ The magnitude of the task of reexamining every water appropriation in California forced the State Water Resources Control Board to adopt a pro forma review of existing permits. ${ }^{164}$ The Federal Court of Claims therefore held that the California public trust doctrine did not preclude a takings claim when the federal government ordered appropriators to divert less water in order to protect flows for steelhead trout. ${ }^{165}$ California also made

162. The point was made even more explicitly in the original first opinion. Cal. Trout, Inc. v. State Water Resources Control Bd., 247 Cal. Rptr. 259, 279 (App. 1988), reh'g granted, 255 Cal. Rptr. 184 (App. 1989); see also Citizens for E. Shore Parks v. Cal. State Lands Comm'n, 136 Cal. Rptr. 3d 162 (App. 2011). Some commentators reached a similar conclusion. See, e.g., Dave Owen, The Mono Lake Case, the Public Trust Doctrine, and the Administrative State, 45 U.C. DAVIS L. REv. 1099 (2012); Thompson, supra note 137, at 1923. Others find greater significance in the public trust language. See, e.g., Blumm \& Doot, supra note 161; Enzler, supra note 137; Kibel, supra note 137, at 38-58; Ronald B. Robie, Effective Implementation of the Public Trust Doctrine in California Water Resources Decision-Making: A View from the Bench, 45 U.C. DAVIS L. REV. 1155 (2012); Melissa K. Scanlaon, Implementing the Public Trust Doctrine: A Lakeside View into the Trustees' World, 39 ECOLOGY L.Q. 123 (2012).

163. See HART, supra note 152; Arnold, supra note 152; Michael C. Blumm \& Thea Schwartz, Mono Lake and the Evolving Public Trust in Western Water, 37 ARIZ. L. REv. 701, 726-35 (1995); Graf, supra note 159; Cynthia L. Koehler, Water Rights and the Public Trust Doctrine: Resolution of the Mono Lake Controversy, 22 Ecol. L.Q. 541 (1995); Littleworth, supra note 154; Roos-Collins, supra note 159.

164. See, e.g., State Water Res. Control Bd. Cases, 39 Cal. Rptr. 3d 189, 271-73 (App. 2006), rev. denied, cert. denied sub nom., Westlands Water Dist. v. State Water Res. Control Bd., 549 U.S. 889 (2006); Golden Feather Cmty. Ass'n v. Termalito Irrigation Dist., 257 Cal. Rptr. 836 (App. 1989); United States v. State Water Res. Control Bd., 227 Cal. Rptr. 161 (App. 1986); see generally Craig Anthony (Tony) Arnold \& Leigh A. Jewel, Litigation's Bounded Effectiveness and the Real Public Trust Doctrine: The Aftermath of the Mono Lake Case, 14 HASTINGS W.-Nw. J. ENVTL. L. \& PoL'Y 1177 (2008); Blumm \& Schwartz, supra note 169, at 720-26, 735-38; Craig, supra note 131, at 104-15; Ellen Hanak et al., Myths of California Water - Implications and Reality, 16 HASTINGS W.-NW. J. ENVTL. L. \& POL'Y 3, 50-53 (2010); Koehler, supra note 169, at 577-85. But see Roos-Collins, supra note 159.

165. Casitas Mun. Water Dist. v. United States, 102 Fed. Cl. 443, 455-61 (Fed. Cl. 2011). But see In re Methyl Tertiary Butyl Ether Prods. Liab. Litig., 824 F. Supp. 2d 524, 546-47 (S.D.N.Y. 2011) (disallowing a trespass claim because California's public trust doctrine precluded the claimant from showing exclusive rights in the possession of the resource). See generally Raymond Dake, Trout of Bounds: The Effects of the Federal Circuit Court of Appeals' Misguided Fifth Amendment Takings Analysis in Casitas Municipal Water District v. United States, 36 Colum. J. EnVTL. L. 59 (2011); John D. Echeverria, The Public Trust Doctrine as a Background Principles Defense in Takings Litigation, 45 U.C. DAVIS L. REV. 931, 955-70 (2012); Josh Patashnik, Physical Takings, Regulatory Takings, and Water Rights, 51 Santa ClaRa L. Rev. 365 (2011); Scott Andrew Shepard, The Unbearable Cost of Skipping the Check: Property Rights, Takings Compensation \& Ecological Protection in the Western Water Law Context, 17 N.Y.U. ENVTL. L.J. 1063 (2009); Thompson, supra note 137. 
enforcement of the public trust more difficult by barring private plaintiffs from suing on behalf of the general public, requiring the plaintiffs to have "suffered injury in fact" involving "lost money or property." "166 Public trust language might occasionally be useful to justify the regulation of private actors, but the regulation might also have been justified under the general police power without a claim of a proprietary interest in the state. ${ }^{167}$

\section{Application of the Public Trust to Riparian Rights}

Riparian rights still apply in three Great Lakes states (Illinois, Indiana, and Pennsylvania). The public trust has rarely been raised in riparian rights litigation. ${ }^{168}$ In the few such cases, the doctrine made even less difference than under appropriative rights, appearing only as a makeweight argument because the public trust doctrine operates between private litigants just like the reasonable use theory of riparian rights. ${ }^{169}$ After a court determines whether a water use is reasonable for the reasonable use theory, a judicial determination of whether it is consistent with the public trust is superfluous. The only utility to the public trust doctrine under riparian rights would be to open standing to new parties ${ }^{170}$ or

166. CAL. Bus. \& PRof. Code $\S 17204$ (Deering 2013).

167. Compare People v. Weaver, 197 Cal. Rptr. 521 (App. Dep't Super. Ct.1983), with Aerojet-General Corp. v. Superior Court, 257 Cal. Rptr. 621, 628-29 (App. 1989), reh'g denied, and Haher's Sodus Point Bait Shop, Inc. v. Wigle, 528 N.Y.S.2d 244 (App. Div. 1988), appeal denied, 532 N.E.2d 101 (N.Y. 1988). See generally Arnold, supra note 152; Arnold \& Jewel, supra note 170; Brian E. Gray, Ensuring the Public Trust, 45 U.C. DAVIS L. REV. 973 (2012); Kibel, supra note 137, at 58-93; Lazarus, supra note 160, at 674-79; Owen, supra note 154; Richard Roos-Collins, Lessons from the Mono Lake Cases for Effective Management of Public Trust Resources, 15 SOUTHEASTERN ENVTL. L.J. 171 (2006).

168. There seem to be only three such cases: Conservation Law Found., Inc. v. Dep't of Envtl. Prot., 823 A.2d 551 (Me. 2003); Anglers of the Ausable, Inc. v. Dep't of Envtl. Quality, 793 N.W.2d 596, 601-03 (Mich. 2010), vacated \& appeal dismissed as moot, 796 N.W.2d 240 (Mich. 2011); Mich. Citizens for Water Conservation v. Nestlé Waters N. Am., Inc., 737 N.W.2d 447, 451 n.8 (Mich. 2007). See generally Stephen N. Bretsen \& Peter J. Hill, Water Markets as a Tragedy of the Anticommons, 33 WM. \& MARY ENVTL. L. \& POL'Y REv. 723, $750-56$ (2009); Noah D. Hall, Protecting Freshwater Resources in the Era of Global Water Markets: Lessons Learned from Bottled Water, 13 U. DENV. WATER L. REV. 1, 46-5.1 (2009). For arguments for more aggressive use of the public trust under riparian rights, see Robin Kundis Craig, Adapting to Climate Change: The Potential Role of State CommonLaw Public Trust Doctrines, 34 VT. L. REv. 781 (2010); Frey \& Mutz, supra note 124; Timothy M. Mulvaney, Instream Flows and the Public Trust, 22 Tul. ENVTL. L.J. 315 (2009); Patrick Parenteau, Come Hell and High Water: Coping with the Unavoidable Consequences of Climate Disruption, 34 VT. L. REV. 957, 962-64 (2010).

169. National Audubon Soc'y v. Superior Court, 658 P.2d 709 (Cal. 1983), cert. denied sub nom. City of Los Angeles Dep't of Water \& Power v. National Audubon Soc'y, 464 U.S. 977 (1983) (holding that the public trust is governed by a standard of "reasonable use").

170. In National Audubon Soc'y, private citizens were allowed to sue on behalf of the public interest. 658 P.2d at 730. But see VT. STAT. ANN. tit. 10, § 1390(5) (2013) (barring 
to a "Public Advocate" as in New Jersey. ${ }^{171}$

This allows courts to move decisions from forums like legislatures and administrative agencies that might be subservient to a well-organized interest group, to a forum in which the diffused interests of a disorganized majority are better represented. ${ }^{172}$ To protect the public interest against narrow private interests, a court could remand a case to an administrative agency with directions to reconsider its decision in light of interests identified by the court. ${ }^{173}$ Courts have held that the public trust cannot be

standing for any private party after the state extended the public trust to groundwater); Neighborhood Action Comm. v. State, 652 So. 2d 693, 697 (La. Ct. App.) (denying standing to invoke the public trust doctrine to anyone who could not show personal interest distinct from that of the general public), cert. denied, 654 So. 2d 352 (La. 1995); Parker v. Town of Milton, 726 A.2d 477, 479-81 (Vt. 1998) (denying standing to town residents and members of labor unions to raise the public trust doctrine when the claimed injury was to economic and employment interests).

171. See The Public Advocate Act of 1975 (codified at N.J. STAT. ANN. $\S \S 52: 27 \mathrm{E}-1$ to 52:27E-47 (West 1984)). The Public Advocate initiated or intervened in legal proceedings on behalf of the "public interest" as defined by the Office of the Public Advocate itself. N.J. Stat. ANN. §§ 52:27E-29-52:27E-30 (West 1984); see Thomas J. Fellig, Pursuit of the Public Trust: Beach Access in New Jersey from Neptune v. Avon to Matthews v. BHIA, 10 Colum. J. EnvTl. L. 35 (1985). New Jersey's legislature abolished the Public Advocate in 1994 , restored it in 2005, and abolished it again in 2010. See 1994 N.J. Laws, ch. 58, $\S 70$ (codified at N.J. STAT. ANN. $\S \S 52: 27 \mathrm{E}-50$ to $52: 27 \mathrm{E}-74$ (West 2010)); N.J. STAT. ANN. § 52:27EE-86 (West 2010); Gormley v. Wood-El, 29 A.3d 336, 338 n.1 (N.J. Super. Ct. App. Div. 2011). Wisconsin had a similar experience with an office called the "Public Intervenor." 1969 Wis. Laws, c. 276, § 485 (codified at WIS. STAT. $§ 165.07$ (Supp. 1994)), renumbered and redesignated, WIS. STAT. $\S 23.39$ (Supp. 1996) (Jason J. Cznarezki, Environmentalism and the Wisconsin Constitution, 90 MARQ. L. REV. 465, 488 n.160 (2007)), repealed, 1997 Wis. Act 783x; see also Jodi Habush Sinykin, At a Loss: The State of Wisconsin After Eight Years Without the Public Intervenor's Office, 88 MARQ. L. REV. 645 (2004); see generally Stanley C. Van Ness, On the Public Advocate's Involvement in Mount Laurel, 14 Seton Hall L. Rev. 832 (1984). The Public Advocate played a major role in expanding the public trust in New Jersey.

172. See, e.g., Leydon v. Town of Greenwich, 750 A.2d 1122 (Conn. App. Ct.) (holding that a town's park ordinance violates the public trust doctrine for discriminating against nonresidents without clear authorization from the state's legislature), rev'd on other grounds, 777 A.2d 552 (Conn. 2001); Borough of Neptune City v. Borough of Avon-by-the-Sea, 294 A.2d 47 (N.J. 1972) (holding that a city's fee for beach usage violates the public trust doctrine for discriminating against non-residents without clear authorization from the state's legislature); see generally Karl P. Baker \& Dwight H. Merriam, Indelible Public Interests in Property: The Public Trust and the Public Forum, 32 B.C. ENVTL. AfF. L. REV. 275, 291-97 (2005); Barton H. Thompson, Jr., The Public Trust Doctrine: A Conservative Reconstruction \& Defense, 15 SOUTHEASTERN ENVTL. L.J. 47, 64-66 (2006). For critiques of this theory, see James L. Huffman, Trusting the Public Interest to Judges: A Comment on the Public Trust Writings of Professors Sax, Wilkinson, Dunning and Johnson, 63 DENV. U. L. REv. 565 (1986); see also Erin Ryan, Comment, Public Trust and Distrust: The Theoretical Implications of the Public Trust Doctrine for Natural Resource Management, 31 ENVTL. L. 477 (2001).

173. The court in National Audubon Soc'y required the State Water Resources Control Board to take a "hard look" at the public trust interests. 658 P.2d at 727. For "remands" to a 
divested by an administrative agency without explicit legislative authority, moving the decision from the agency to the legislature. ${ }^{174}$ Legislative conveyances of trust property into private hands must be clear and explicit; the public will not lose its beneficial interest in lands or waters through carelessness or legerdemain. ${ }^{175}$

This procedural view of the public trust doctrine provides a check on unbridled greed, but it hardly creates an insuperable barrier to the development of, or export of, water from the Great Lakes. If the pressure for development or export is great enough, a legislature or agency will succumb to narrow private interests and authorize the action even after a "hard look." Yet, to do more, to hold that the court is final arbiter of how resources are to be used, is undemocratic to say the least. ${ }^{176}$ Without judicial power to determine how resources are used leaves, however, only a call to legislative responsibility. ${ }^{177}$ Whoever enforces the public trust, however, is likely to find that the requisite balancing process transforms the values expressed in the doctrine from incommensurable moral claims into rather ordinary issues regarding the monetary worth of competing uses of

legislature see, e.g., Ill. Cent. R.R. v. Illinois, 146 U.S. 387 (1892); National Ass'n of Home Bldrs. v. New Jersey Dep't of Envtl. Prot., 64 F. Supp. 2d 354 (D.N.J. 1999); and In re Wai'ola o Moloka'i, Inc., 83 P.3d 664, 684-85 (Haw. 2004). See generally William D. Araiza, Democracy, Distrust, and the Public Trust: Process-Based Constitutional Theory, the Public Trust Doctrine, and the Search for a Substantive Environmental Value, 45 UCLA L. REv. 385, 438-52 (1997); Jeffrey W. Henquinet \& Tracy Dobson, The Public Trust Doctrine and Sustainable Ecosystems: A Great Lakes Fisheries Case Study, 14 N.Y.U. ENVTL. L.J. 322, 344-47 (2006); Thompson, supra note 164, at 66.

174. See Leydon v. Town of Greenwich, 777 A.2d 552 (Conn. 2001); Bos. Waterfront Dev. Corp. v. Commonwealth, 393 N.E.2d 356 (Mass. 1979); Comm. to Save the Upper Androscoggin v. N.H. Water Res. Bd., 466 A.2d 1308 (N.H. 1983); Morse v. Or. Div. of State Lands, 590 P.2d 709 (Or. 1979); Town of Warren v. Thornton-Whitehouse, 740 A.2d 1255 (R.I. 1999); State v. Fain, 259 S.E.2d 606 (S.C. 1979).

175. See, e.g., Berkeley v. Superior Court, 606 P.2d 362 (Cal. 1980), cert. denied sub nom. Santa Fe Land Improvement Co. v. Berkley 449 U.S. 840 (1980); State v. Sorenson, 436 N.W.2d 358 (Iowa 1989); Borough of Neptune City, 294 A.2d 47.

176. Huffman, supra note 164; Lazarus, supra note 146, at 712-13.

177. See, e.g., Cal. Earth Corps v. Cal. State Lands Comm'n, 27 Cal. Rptr. 3d 476 (App. 2005) (voiding an exchange of ten acres of tidelands for ten acres of fast land to enable construction of an entertainment and retail complex for lack of evidence of the effect on the public trust), rev. dismissed, 127 P.3d 28 (Cal. 2006); In re Water Use Permit Application Filed by Kukui, 174 P.3d 320, 346-48 (Haw. 2007) (the burden of proof regarding impacts on the public trust lies on the one seeking to make a use affecting the public trust even after the administering agency found in the favor of that party); In re Water Use Permit Applications (I), 9 P.3d 409 (Haw. 2000) (requiring a close look at the administrative decision), further appeal, 93 P.3d 643, 650 (Haw. 2004) (same); see also Baker \& Merriam, supra note 164; Henquinet \& Dobson, supra note 165, at 344-47; Lazarus, supra note 146, at 679-710. But see Araiza, supra note 165, at 430-38 (arguing for courts to embrace "substantive values" in enforcing the public trust); Peter Manus, To a Candidate in Search of an Environmental Theme: Promote the Public Trust, 19 STAN. ENVTL. L.J. 315 (2000) (arguing that the public trust requires governments to undertake ecological rehabilitation). 
water. ${ }^{178}$ This transformation might be even more troubling than the challenge to democratic theory. Either way, the doctrine as applied to riparian rights is not likely to prove a serious barrier to the export of water from the Great Lakes watershed.

\section{The Public Trust and Regulated Riparianism}

Five Great Lakes states have enacted regulated riparian statutes (Michigan, Minnesota, New York, Ohio, and Wisconsin). ${ }^{179}$ In regulated riparian states, the determination of whether a water use is reasonable is made by an administrative agency rather than by a court, creating a potential opening for a court to re-examine the question of reasonableness under the public trust doctrine. Until recently, courts in all but one regulated riparian state rebuffed efforts to overturn agency decisions as violations of the public trust in the few cases where the issue was raised - cases that did not involve water allocation decisions. ${ }^{180}$ The great majority of cases in regulated riparian states involving natural resources or the environment (and not water at all) in which the public trust is raised are from Connecticut, which enacted the public trust doctrine in a statute that has become a routine citation that has never actually affected the outcome of the cases. ${ }^{181}$ Moreover, most of these cases were suits against a governmental entity, rather than against a private party. Connecticut's Supreme Court, in fact, has explicitly held that the public trust in the waters of the state does not operate independently of specific statutory standards if those standards apply to the issues before the court. ${ }^{182}$

178. See generally Laurence H. Tribe, Ways Not to Think about Plastic Trees: New Foundations for Environmental Law, 83 YALE L.J. 1315 (1974); Harry H. Wellington, Common Law Rules and Constitutional Double Standards: Some Notes on Adjudication, 83 YALE L.J. 221 (1973); Michael L. Rustad, Smoke Signals from Private Attorneys General in Mega Social Policy Cases, 51 DePAUL L. REV. 511 (2001).

179. Mich. CoMp. LaWS ANN. $\S \S 324.32701-324.32803$ (West 2013); MINN. STAT. ANN. $\S \S 103 G .001-103 G .315$ (West 2013); N.Y. ENVTL. CONSERV. LAW §§ 15-1501-15-1529 (McKinney 2013); OHIO REV. CODE ANN. $\S \S 1501.30-1501.35$ (West 2013); WIS. STAT. ANN. $\S \S 30.18,30.28,30.292-30.298,281.35$ (West 2013).

180. St. Croix Waterway Ass'n v. Meyer, 178 F.3d 515 (8th Cir. 1999) (referring to the laws of Minnesota and Wisconsin); Froebel v. Wis. Dep't of Natural Res., 579 N.W.2d 774, 781-82 (Wis. Ct. App. 1998).

181. See ConN. Gen. Stat. ANN. § 22a-19(a) (West 2013). For the pro forma references just in 2012, see Shanahan v. Dep't of Envtl. Prot., 47 A.3d 364, 385 n.26 (Conn. 2012); Conservation Comm'n v. Red 11, 43 A.3d 244, 252-53 (Conn. App. Ct. 2012); Fort Trumbull Conservancy v. City of New London, 43 A.3d 679, 687-89 (Conn. App. Ct. 2012); Batchelder v. Planning \& Zoning Comm'n, 34 A.3d 465, 467 n.1 (Conn. App. Ct.), cert. denied, 40 A.3d 319 (Conn. 2012).

182. See, e.g., Burton v. Comm'r of Envtl. Prot., 970 A.2d 640, 648 (Conn. 2009); Andross v. Town of W. Hartford, 939 A.2d 1146, 1155-56 (Conn. 2008); City of Waterbury v. Town of Wash., 800 A.2d 1102, 1138, 1140 (Conn. 2002); see also Lake Beulah Water 
In Hawaii the public trust arguably has had an effect on the administration of the state's regulated riparian law. ${ }^{183}$ The Hawaiian Supreme Court has been unable to explain how the public trust doctrine actually changed the outcome of the cases in which the court has invoked it. ${ }^{184}$ The Hawaiian Supreme Court first referred the public trust doctrine as applicable to fresh waters in Hawaii in Robinson v. Ariyoshi (II). ${ }^{185}$ In Robinson, however, the court resorted to the public trust doctrine only in order to avoid a finding that an earlier decision ${ }^{186}$ had been a taking of property ${ }^{187}$ Hawaii had amended its constitution in 1978 , four years before Robinson, to incorporate the substance (but not the name) of the public trust doctrine. ${ }^{188}$ The issues litigated at such length in Robinson and the earlier case, however, were largely rendered moot by the Hawaiian Water Code which in $1987^{189}$ made Hawaii a regulated riparian state.

The role of the public trust doctrine in the administration of the Hawaiian Water Code first arose in In re Water Use Permit Applications (I). ${ }^{190}$ After a contested hearing involving numerous parties and extending over two years, the Commission on Water Resources Management ordered the restoration of $10.4 \mathrm{mgd}$ to the flows of the streams that supplied the Wai'ahole Ditch on Oahu and allocated more than $13 \mathrm{mgd}$ to off-stream

Mgmt. Dist. v. State Dep't Nat. Res., 799 N.W.2d 73, 84-85 (Wis. 2011); see generally Scanlan, supra note 124; Scott B. Simpson, Note, Forging Connecticut's Water Policy Future: Registered Diversions, Riparian Rights and the Courts after Waterbury v. Washington, 8 CONN. PUB. INT. L.J. 255, 289-92 (2009).

183. In re Wai'ola o Moloka'i, 83 P.3d at 699-701; In re Water Use Permit Applications (I), 9 P.3d at 439-56 (already cited explanatory phrase in FN 183); see also David L. Callies \& Calvert G. Chipchase, Water Regulation, Land Use and the Environment, 30 U. HAW. L. ReV. 49 (2007); Keala C. Ede, He Kanawai Pono no ka Wai (A Just Law for Water): The Application and Implications of the Public Trust Doctrine in In re Water Use Permit Applications, 29 ECOLOGY L.Q. 283 (2002); Mulvaney, supra note 160, at 354-60, 365-67; D. Kapua'ala Sproat, Wai through Kanawai: Water for Hawai' $i$ 's Streams and Justice for Hawaiian Communities, 95 MARQ. L. Rev. 127 (2011); Symposium, Managing Hawaii's Public Trust Doctrine, 24 U. HAW. L. REv. 1 (2001).

184. For an ambitious attempt to stake an independent substantive role for the public trust doctrine in Hawai'i, see Sproat, supra note 175; D. Kapua'ala Sproat, Where Justice Flows Like Water: The Moon Court's Role in Illuminating Hawai'i Water Law, 33 U. HAW. L. REV. 537 (2011) [hereinafter Sproat, Justice].

185. 658 P.2d 287, 310-12 (Haw. 1982).

186. McBryde Sugar Co. v. Robinson, 504 P.2d 1330 (Haw. 1973), aff'd on rehearing, 517 P.2d 26 (Haw. 1973), appeal dismissed sub nom. McBryde v. Hawaii, 417 U.S. 962 (1974).

187. Robinson v. Ariyoshi (I), 441 F. Supp. 559 (D. Haw. 1977), aff'd in part, 753 F.2d 1468 (9th Cir. 1985), vacated, 477 U.S. 902 (1986); see generally Williamson B.C. Chang, Judicial Takings: Robinson v. Ariyoshi Revisited, 21 WIDENER L.J. 655, 663-73 (2012).

188. HAW. CONST. art. XI, $\S 1$.

189. HAW. REv. STAT. ANN. $\S \S 174 C-1-174 C-10$ (LexisNexis 2013).

190. 9 P.3d 409 (Haw. 2000); see generally Christine Daleiden, Hawaii's Ditch Systems: Water Allocation after Sugar Cane, HAw. B.J., July 2006, at 28; Sproat, Justice, supra note 176 , at $552-60$. 
uses from the ditch. ${ }^{191}$ The court, in a four-to-one decision written by Justice Paula Nakayama, concluded that the legal protection of minimum flows in the Water Code expresses the public trust ${ }^{192}$ and that the Hawaiian public trust extends to all waters--surface waters, groundwater, and "all other water." 193 She also concluded that the public trust protected not only navigation, commerce, and fishing, but also recreation, domestic uses, ecological interests, and native Hawaiian traditional rights, ${ }^{194}$ but did not protect private commercial uses. ${ }^{195}$ She charged the Commission to balance the trust purposes against the need for "reasonable-beneficial" water uses for private purposes. ${ }^{196}$

Justice Nakayama insisted that the public trust doctrine is not simply a restatement of the Commission's prerogatives under the Hawaiian Water Code ${ }^{197}$ She did not, however, explain how invocation of the public trust doctrine added anything to the terms of the Code. ${ }^{198}$ The closest she came was to insist that the trust imposed an "affirmative duty" to protect the water necessary to achieve its purposes-a duty tempered by the need to accommodate consumptive human uses of water. ${ }^{199}$ The only real difference

191. In re Water Use Permit Applications (I), 9 P.3d at 423-30; see generally Callies \& Chipchase, supra note 175; Mulvaney, supra note 160, at 356-57.

192. In re Water Use Permit Applications (I), 9 P.3d at 439-56. Curiously, Justice Nakayama did not refer to the state constitutional provision expressing public trust values. See Denise E. Antolini \& Clifford L. Rechtschaffen, Common Law Remedies: A Refresher, 38 Envtl. L. Rptr. (Envtl. Law Inst.) 10114, 10125-26 (2008) (concerning Nakayama's analysis); see also Callies \& Chipchase, supra note 175, at 68-77; Craig, supra note 160, at 838-41; Ede, supra note 175; Mulvaney, supra note at 160, at 354-60, 365-69; Symposium, supra note 175; Summer Sylva, Note, Indigenizing Water Law in the 21st Century: Na Moku Aupuni O Ko'olau Hui, a Native Hawaiian Case Study, 16 CoRnell J.L. \& PuB. Pol'y 563, 568-76 (2007).

193. In re Water Use Permit Applications (I), 9 P.3d at 445-47; see also Ede, supra note 175 , at 307-10.

194. In re Water Use Permit Applications (I), 9 P.3d at 448-50; see also In re Water Use Permit Application Filed by Kukui, 174 P.3d 320; Ho'opulapula v. Bd. of Land \& Natural Res., 143 P.3d 1230 (Haw. 2006); Kalima v. State, 137 P.3d 990 (Haw. 2006); Maui Tomorrow v. State, 131 P.3d 517 (Haw. 2006); see generally Andrew R. Carl, Note, Method Is Irrelevant: Allowing Native Hawaiian Traditional and Customary Subsistence Fishing to Thrive, 32 U. HAw. L. REV. 203 (2009); Ede, supra note 175, at 298-99, 309-10; Jodi Higuchi, Comment, Propagating Cultural Klpuka: The Obstacles and Opportunities of Establishing a Community-Based Subsistence Fishing Area, 31 U. HAw. L. REv. 193 (2008).

195. In re Water Use Permit Applications (I), 9 P.3d at 449-50.

196. Id. at 450-55; see also Ede, supra note 175, at 298-303, 305-07, 309-13.

197. In re Water Use Permit Applications (I), 9 P.3d at 454-55; see also Mulvaney, supra note 160 , at $358-59$.

198. In re Water Use Permit Applications (I), 9 P.3d at 431; see also Callies \& Chipchase, supra note at 175, at 50-77 (arguing that the court was wrong as a matter of statutory interpretation and as a matter of policy); Mulvaney, supra note 160, at 365-69 (arguing that the decision established the public trust as a distinct and powerful tool for reigning in water usage).

199. In re Water Use Permit Applications (I), 9 P.3d at 453-54; see also Mulvaney, supra 
the public trust made seems to have been justifying the court in taking a "close look" at the Commission's decision. ${ }^{200}$ The court largely affirmed the Commission's factual findings, but remanded the case for further proceedings to ensure that the Commission adequately considered the "precautionary principle."201 Justice Mario Ramil dissented on the grounds that the Water Code displaced all common law claims, including the public trust doctrine, and thus gave no privileged place to protecting instream flows. $^{202}$

Hawaii's Supreme Court has considered the role of the public trust under the Hawaiian Water Code in several other cases. Justice Steven Levinson, writing for a unanimous court in In re Wai'ola o Moloka' ${ }^{2}{ }^{203}$ affirmed the Commission's findings and held that the proposed permit was consistent with its previously announced standard-a balancing of the public interest (including protection of the environment) against the "economic and efficient" use of the water, ${ }^{204}$ all without violating the rights of established users. ${ }^{205}$ Nevertheless, he reversed the Commission for failure to provide adequate protection to the public trust, without indicating what standard was to be applied. ${ }^{206}$ This decision was the first decision actually applying the public trust to void a permit granted under a regulated riparian statute and is also is the only actual application anywhere of the public trust doctrine to groundwater. ${ }^{207}$

While Wai'ola o Moloka'i was under consideration, In re Water Use Permit Applications (II) ${ }^{208}$ returned to the court after its remand. Justice Nakayama again delivered the opinion, declaring that courts were responsible for interpreting and applying the public trust doctrine, but that this responsibility merely requires a "close look" to ensure that legislative or agency decisions are made with the openness, diligence, and foresight commensurate to the high priority accorded the public rights under the public trust doctrine. ${ }^{209}$ She then reversed the Commission for relying on

note 160 , at 357-60, 365-67.

200. In re Water Use Permit Applications (I), 9 P.3d at 454-56.

201. Id. at 458-72; see also In re Water Use Permit Application Filed by Kukui, 174 P.3d at $336-38,346-48$ (holding that the precautionary principle was implicit in the requirement of sustainability).

202. In re Water Use Permit Applications (I), 9 P.3d at 502-10 (Romil, J., dissenting).

203. 83 P.3d 664.

204. Id. at 699-701.

205. Id. at $687-89$.

206. Id. at 687-97.

207. See Samantha Bohrman, Groundwater Conservation and Coalbed Methane Development in the Powder River Basin, 24 LAw \& INEQ. 181, 198-99 (2006).

208. In re Water Use Permit Applications (II), 93 P.3d 643.

209. Id. at 650, 658-59; see also Kelly v. 1250 Oceanside Partners, 140 P.3d 985 (Haw. 2006); see generally Callies \& Chipchase, supra note 175, at 95-96; Charley F. Ice, Jason K. Levy, \& Clark C.K. Liu, The Hawaiian Commission on Water Resource Management and the Water Code: Protecting the Public Trust, 7 Water ResourCes IMPACT no. 2, at 13 (Mar. 2005); Sproat, Justice, supra note 176, at 560-63. 
speculative evidence without an adequate weighing of the public and private interests in setting instream flow standards. ${ }^{210}$ The burden of proving consistency with the public trust fell on permit applicants. ${ }^{211}$ She closed by noting that the Commission was not obligated to ensure any applicant's access to less expensive sources of water, so long as alternatives were available and public values would be compromised by allowing use of the less expensive waters. ${ }^{212}$

Subsequent Hawaiian cases involved the application of the public trust to water quality standards ${ }^{213}$ and native Hawaiian rights. ${ }^{214}$ Perhaps the most important addition to public trust jurisprudence from these cases is a statement that the state's duty under the public trust is as a guardian and trustee and therefore is not satisfied merely by fulfilling the duties of a good business manager. ${ }^{215}$ All of this leaves us with several cases in which a permit issued under a regulated riparian statute was voided for violating the public trust doctrine without the court developing a theory to differentiate the effect of the doctrine from the statutory standards already embedded in the Hawaiian Water Code. The same decisions could have been reached had the Hawaiian courts adopted the view of the Connecticut Supreme Court that regulated riparian statutes express and exhaust public trust requirements. ${ }^{216}$

\section{E. The Public Trust and the Great Lakes}

Despite the high hopes that some hold for the public trust doctrine as the ultimate protector of the integrity of the Great Lakes, ${ }^{217}$ the doctrine is likely to have no greater effect than under traditional riparian rights ${ }^{218}$ and regulated riparianism. ${ }^{219}$ The public trust doctrine could conceivably

210. In re Water Use Permit Applications (II), 93 P.3d at 651-55.

211. Id. at 657-58; see also In re Water Use Permit Application Filed by Kukui, 174 P.3d at $336-38,346-48$.

212. In re Water Use Permit Applications (II), 93 P.3d at 661-62.

213. See, e.g., Kelly, 140 P.3d 985 (Haw. 2006).

214. See, e.g., In re Water Use Permit, 174 P.3d 320; Hui Kako'o Aina Ho'Opulapula v. Board of Land \& Nat. Res, 143 P.3d 1230 (Haw. 2006); Kalima v. State, 137 P.3d 990 (Haw. 2006); Maui Tomorrow v. State, 131 P.3d 517 (Haw. 2006).

215. See, e.g., Kelly, 140 P.3d at 1011; see generally Sarah K. Kam, Comment, Biopiracy in Paradise?: Fulfilling the Legal Duty to Regulate Bioprospecting in Hawaii, 28 U. HAW. L. REV. 387, 412-22 (2006) (exploring the implications of a "positive duty" to protect the natural environment); Adirenne Iwamoto Suarez, Comment, Avoiding the Next Hokuli'a: The Debate over Hawaii's Agricultural Subdivisions, 27 U. HAw. L. Rev. 441 (2005) (arguing that legislation to regulate public trust lands is necessary to fulfill the state's public trust obligations).

216. See the authorities collected supra at note 174 .

217. See the authorities collected supra at note 124.

218. See Pt. III(C) supra.

219. See Pt. III(D) supra. 
revolutionize water allocation law under appropriative rights, but in practice its application has had little effect. ${ }^{220}$ When courts approve the construction of sports stadiums, hotels, shopping centers, and vast parking lots in the Northeast's largest wetland as consistent with the public trust doctrine, ${ }^{221}$ one can only conclude that the public trust doctrine is too weak to preserve natural hydraulic systems intact in the face of persistent pressures for development. One can argue that such decisions were wrong, but they happen too often to justify an expectation that the doctrine will preclude ecocide or ensure less destructive development of natural resources. The public trust stiffens the environmental impact assessment process, but it is not an absolute bar to development of protected natural resources.

\section{STATUTORY LIMITATIONS ON THE EXPORT OF WATER FROM THE GREAT LAKES BEFORE THE GREAT LAKES WATERSHED WATER RESOURCES COMPACT}

In the early 1980s, proposals to divert water from the Great Lakes to recharge the Ogallala Aquifer by spreading water on the ground in South Dakota, from which it would eventually percolate down to New Mexico and west Texas, provoked considerable debate in the law reviews. ${ }^{222}$ Illinois, to enforce the outcome of extensive and lengthy original litigation, before the US Supreme Court had confirmed their right to divert water for use in and near Chicago but outside the Great Lakes watershed, had already prohibited the withdrawal of water from Lake Michigan without a state permit. ${ }^{223}$ The clamor over the Ogallala proposals led legislatures in most of

220. See Pt. III(B) supra.

221. See, e.g., New Jersey Sports Auth. v. McCrane, 61 N.J. 1, 292 A.2d 545, appeal dismissed sub nom. Borough of East Rutherford v. New Jersey Sports Auth., 409 U.S. 943 (1972), on remand sub nom. In re Sports Complex at Hackensack Meadowlands, 62 N.J. 248, 300 A.2d 337, cert. denied, 414 U.S. 989 (1973).

222. On the proposals to divert, see Bulkley, Wright, \& Wright, supra note 14; Sheets, supra note 14. On the debate, see Robert H. Abrams, Interbasin Transfer in a Riparian Jurisdiction, 24 WM. \& MARY L. REV. 591, 608-23 (1983); Patrick E. Corbett, Note, The Overlooked Farm Crisis: Our Rapidly Depleting Water Supply, 61 N. DAME L. REv. 454 (1986); David Hoffman, Note, Who Owns the Great Lakes? Posturing for Control of an International Resource, 16 CASE W. RES. J. INT'L L. 71 (1984); Mitch Irwin, Guarding the Great Lakes, 64 Mich. BAR J. 397 (1985); Robert W. Tubbs, Comment, Great Lakes Water Withdrawal: Federal Authority over Great Lakes Water, 3 DET. COLL. L. REV. 919 (1983); Julia R. Wilder, Note, The Great Lakes as a Water Resource: Questions for Ownership and Control, 59 IND. L. REV. 463 (1984).

223. The current version of the Illinois permit statute is 615 ILL. COMP. STAT. $\S \S 50 / 1$ $50 / 14$ (2013). For the original litigation, see Wisconsin v. Illinois, 449 U.S. 48 (1980); Wisconsin v. Illinois, 388 U.S. 426 (1967); Wisconsin v. Illinois, 289 U.S. 395 (1933); Wisconsin v. Illinois, 281 U.S. 696 (1930); Wisconsin v. Illinois, 278 U.S. 367 (1929); New York v. Illinois, 274 U.S. 488 (1927); Sanitary Dist. v. United States, 266 U.S. 405 (1925). On the mechanics of the Chicago withdrawals, see Brett Hansen, The Reversal of the 
the other Great Lakes states and eventually Congress to enact statutes banning out-of-basin or out-of-state withdrawals. ${ }^{224}$

Minnesota was the first state to act, banning withdrawals in 1983 for out-of-state uses unless the legislature approved the withdrawal and the state's Commissioner of Natural Resources found that Minnesota would still have sufficient water to meet all foreseeable needs. ${ }^{225}$ Indiana followed in 1984, banning withdrawals of water from Lake Michigan without the consent of the governor of each Great Lakes state. ${ }^{226}$ At almost the same time, Illinois undertook to revise its "Level of Lake Michigan Act" by adding a requirement of a permit for any new or increased use of Lake Michigan water in excess of an average of $2 \mathrm{mgd}$ in any 30-day period. ${ }^{227}$ Illinois's new legislation also prohibited permits for the use of water outside the boundaries of any Great Lakes state "without the approval of the other Great Lakes states and the International Joint Commission."228

Wisconsin in 1985 adopted an elaborate scheme for managing largescale water withdrawals in the state. ${ }^{229}$ Among other provisions, the statute banned withdrawals that would have "a significant adverse impact on the environment and ecosystem of the Great Lakes basin or the upper Mississippi river basin., ${ }^{, 230}$ Wisconsin also required its Department of Natural Resources to solicit comments from the governors of the other Great Lakes states, the premiers of Ontario and Québec, the water management agencies of those states and provinces, and, if required by the governing treaty, the International Joint Commission, for new withdrawals from the Great Lakes "ecosystem" averaging more than $5 \mathrm{mgd}$ in a thirtyday period. ${ }^{231}$ Joe Sax was so impressed by the Wisconsin approach that he based a model act on it that influenced legislators in Minnesota and New York. ${ }^{232}$ Michigan, however, chose to go in a different direction, enacting its "Great Lakes Preservation Act" in 1985 under which new withdrawals for transportation out of the Great Lakes basin were simply banned. ${ }^{233}$

The several statutes differed in ways that could have affected their validity under the US Constitution. Michigan alone banned all out-of-basin withdrawals. Illinois, Indiana, and Minnesota banned out-of-state, but not out-of-basin, withdrawals. This difference reflects the geographic fact that

Chicago River: Flushing the System, CiviL ENG'G, Dec. 2009, at 40.

224. The lone exception is Pennsylvania. Vermont would also be an exception if you count it as a Great Lakes state.

225. MINN. STAT. § 103G.265 (amended 2013).

226. IND. CODE § 14-25-1-11 (2013).

227. 615 Ill. COMP. STAT. $\$ 50 / 14(2013)$.

228. Id. $\S 50 / 1.2$.

229. WIS. STAT. $\S 281.35$ (2013).

230. Id. $\S 281.35(5)(\mathrm{d})(4)$. Together these two basins included the entire state.

231. Id. $\S \S 281.35(5)(\mathrm{b}), 281.35(11)$.

232. Joseph L. Sax, A Model State Water Act for Great Lakes Management: Explanation and Text, 18 CASE W. RES. J. INT'L L. 219 (1986).

233. Мich. COMP. LAWS $\S \S 324.32703,324.32704$ (1985). 
virtually all of Michigan is within the Great Lakes watershed, ${ }^{234}$ whereas Illinois, Indiana, and Minnesota straddle the divides between the Great Lakes and Mississippi watersheds. ${ }^{235}$ Michigan's ban could have little effect on most planned withdrawals in Michigan; a withdrawal for use in a neighboring state or province would most likely be for use in the watershed. Direct bans on out-of-state withdrawals, as in Illinois, Indiana, and Minnesota, were suspect as a violation of the dormant commerce clause. ${ }^{236}$ Wisconsin was in the strongest position because it banned even intrastate and intrabasin withdrawals if they would impair the ecosystems in the state. Yet by coordinating with Ontario and Québec, Wisconsin's statute arguably ran afoul of the foreign affairs power of the federal government. ${ }^{237}$ The Michigan ban initially contained a self-destruct clause, perhaps out of fear that it violated federal law. ${ }^{238}$

Besides the risk of preemption by federal law, these statutes could be repealed or amended by any future legislature. The statutes were perhaps better than the fast eroding strictures of riparian rights or the recently enacted general regulated riparian statutes, but only marginally so. At this point, Congress intervened with the Water Resources Development Act of 1986 ("the $\left.1986 \mathrm{Act}^{2}\right)^{239}$ to ratify the state legislation protecting the Lakes. The 1986 Act prohibited the export of water from the Great Lakes watershed and also prohibited federal agencies from studying the possibility

234. A tiny corner of southwestern Michigan falls within the Ohio/Mississippi watershed.

235. Part of Minnesota falls within the Hudson's Bay watershed.

236. See the authorities collected supra note 112 .

237. WIS. STAT. $\S 281.35(5)$ (b). For classic statements of the federal dominance of the foreign affairs power, see American Ins. Ass'n v. Garamendi, 539 U.S. 396 (2003); Crosby v. National Foreign Trade Council, 530 U.S. 363 (2000); Zschernig v. Miller, 389 U.S. 429 (1968); United States v. Curtiss-Wright Export Corp., 299 U.S. 304, 318 (1936); see also Michael J. Donahue, Strengthening the Binational Great Lakes Management Effort: The Great Lakes Commission's Provincial Membership Initiative, 1998 TOL. J. GREAT LAKES' L. SCI. \& PoL'Y 27; H. Patrick Glenn, Reconciling Regimes: Legal Relations of States and Provinces in North America, 15 ARIZ. J. INT'L \& COMP. L. 255 (1998); Peter R. Jennetten, Note, State Environmental Agreements with Foreign Powers: The Compact and the Foreign Affairs Powers of the United States, 8 GEO. INT'L ENVTL. L. REV. 141 (1995); Edward T. Swaine, Does Federalism Constrain the Treaty Power?, 103 CoLUM. L. REv. 403 (2003). For other preemption issues, see Robert Haskell Abrams, Water Federalism and the Army Corps of Engineers' Role in Eastern States Water Allocation, 31 U. ARK.-L.R. L. REV. 395 (2009).

238. Мich. COMP. LAws $§ 323.76$ (1985) (repealed 1990) (sunsetting the law on Dec. 31, 1992).

239. Water Resources Development Act of 1986, Pub. L. No. 99-662, tit. XI, $\$ 1109,100$ Stat. 4230 (enacted Nov. 1986); Pub. L. No. 100-4, tit. V, 101 Stat. 88 (enacted Feb. 1987), codified at 42 U.S.C. § 1962d-20 (2013); see generally Dellapenna, supra note 2, at 859-64; Charles F. Glass, Jr., Note, Enforcing Great Lakes Water Export Restrictions Under the Water Resources Development Act of 1986, 103 CoLuM. L. REv. 1503 (2003); Noah D. Hall, Toward a New Horizontal Federalism: Interstate Water Management in the Great Lakes Region, 77 U. Colo. L. REV. 405, 428-31 (2006); Hinkle, supra note 15, at 310-12. 
of exporting water from the Great Lakes watershed-except if the withdrawal or study received the approval of the governor of every Great Lakes state. ${ }^{240}$ The constitutionality of this statute under the congressional power to regulate commerce has never been challenged. Challenges to similar exercises of congressional power under the commerce clause, such as the Endangered Species Act, have been rejected out of hand. ${ }^{241}$ Nor has the 1986 Act been challenged politically. When Congress revisited the provisions of the 1986 Act in 2001, it strengthened rather than weakened the position of the Great Lakes states. ${ }^{242}$

With the 1986 Act on the books, the state statutes became superfluous, and the states lost the unilateral power to repeal their prohibition of exports of water from the Great Lakes watershed; they could not authorize exports unless the governors of every other state went along. The Illinois, Indiana, and Minnesota statutes were preempted to the extent they authorized in-state but out-of-basin withdrawals. No one ever raised the question of whether the Michigan statute, which arguably barred that state's governor from consenting to an out-of-basin withdrawal, was preempted by the federal act. Michigan's governor could and did-without fear of retaliation-veto proposed withdrawals in any other state if the withdrawals were to cross the watershed boundary. ${ }^{243}$ No governor of any other state could have any say in any proposed withdrawal within Michigan because those withdrawals would be entirely within the Great Lakes watershed. The Wisconsin prohibition of withdrawals probably survived preemption because that ban merely established the standard for consenting to withdrawals and was not an outright ban.

Although a state statute was unnecessary after the 1986 Act, Minnesota and New York enacted new statutes in 1987. These statutes are similar to Wisconsin's statute. ${ }^{244}$ Minnesota added a special subsection for the Great Lakes requiring its Commissioner of Natural Resources to solicit comments from the governors of the other Great Lakes states, from the premiers of Ontario and Québec, the water management agencies of those

240. 42 U.S.C. $\S \S 1962 d-20(b)(3), 1962 d-20(b)(4), 1962 d-20(d), 1962 d-20(e)$ (2013).

241. See, e.g., GDF Realty Investments, Ltd. v. Norton, 326 F.3d 622 (5th Cir. 2003), cert. denied, 545 U.S. 1114 (2005); Rancho Viejo, LLC. v. Norton, 323 F.3d 1062 (D.C. Cir. 2003), cert. denied, 540 U.S. 1218 (2004).

242. See infra text accompanying notes $246-49$.

243. See, e.g., A RePORT ON THE PROPOSED EXPANSION OF THE CITY OF AKRON Water SYSTEM (July 1996) [hereinafter CITY OF AKRON WATER SYSTEM] (discussing a proposed withdrawal to Akron, Ohio, that was allowed only on condition that the city pay to pump the wastewater back into the Great Lakes watershed); Daniel A. Injerd, Managing Great Lakes Water Withdrawals: A Withdrawal Manager's Viewpoint, 1 Buff. ENVTL. L.J. 299 (1993) (discussing a proposed withdrawal to Lowell, Indiana, that was vetoed by the governor of Michigan). These incidents are described in the text infra at notes 289-90.

244. The similarities were probably due to the influence of Joe Sax. See Sax, supra note 224. 
states and provinces, and the International Joint Commission, for new withdrawals averaging more than $5 \mathrm{mgd}$ in a thirty-day period. ${ }^{245}$ Despite these consultation requirements, the Minnesota act reserves the final decision to the Commissioner and to the Minnesota legislature. ${ }^{246}$ Inclusion of the premiers and water management agencies of the Canadian provinces in the consultation scheme arguably intruded on federal prerogatives, while Minnesota's failure to defer to objections from governors of another Great Lakes state is preempted by the inconsistent federal requirement. ${ }^{247} \mathrm{New}$ York in 1989 prohibited new withdrawals of water averaging more than 5 mgd during a thirty-day period until after consultations exactly like those provided for in the Minnesota statute. ${ }^{248}$ The New York statute thus could run afoul of the federal statute to the same extent as the Minnesota statute. New York's statute, alone of the statutes adopted thus far, included a provision spelling out the procedures necessary to secure the governor's approval upon request from the appropriate authorities in another state. ${ }^{249}$

Ohio, which did not have a statute before the 1986 Act, in 1988 enacted a statute prohibiting out-of-basin withdrawals of more than 100,000 gallons per day from either the "Lake Erie drainage basin" or the Ohio River drainage basin without a state permit. ${ }^{250}$ The "Lake Erie drainage basin" includes Ohio's portion of the Great Lakes watershed, while the Ohio River basin includes the rest of the state. Ohio requires the Director of Natural Resources to consult the other Great Lakes states and provinces regarding the Lake Erie basin and prohibits the issuance of a permit without the approval of the other Great Lakes governors. ${ }^{251}$ No similar multistate approval requirement applies to withdrawals from the Ohio basin. The Ohio watershed part of the statute is open to question under the dormant commerce clause.

Congress returned to the 1986 Act in $2001 .^{252}$ Revisions introduced a requirement for consultations with the Canadian provinces of Ontario and Québec-perhaps resolving questions about the constitutionality of comparable provisions in several of the state statutes. ${ }^{253}$ The 2001 amendments reiterated the prohibition of the withdrawal of water out of the

245. MINN. STAT. § 103G.265(4) (amended 2013).

246. Id. $\S \S 103 G .265(4)(\mathrm{a})(2), 103 \mathrm{G} .265(3), 103 \mathrm{G} .265(4)(\mathrm{b})$ (amended 2013).

247. 42 U.S.C. $\S 1962 d-20$ (d) (2013).

248. N.Y. ENVTL. CONSERV. LAW §§ 15-1607, 15-1611 (repealed 2013). The requirement of legislative approval is found at $i d . \S 15-1613(5)(\mathrm{i})$. The entire statute, The Great Lakes Water Conservation and Management Act of 1989, is id. $\S \S 15-1601-15-1615$.

249. Id. \$15-1613.

250. OHIO REV. CODE ANN. $\S 1501.30-1501.35$ (West 2013).

251. Id. $\S 1501.32(\mathrm{C})$.

252. Water Resources Development Act of 2000, Pub. L. 106-541, tit. V, § 504(a), (b), 114 Stat. 2644 (2001), codified at 42 U.S.C. $\S \S 1962 d-20(b)(2), 1962 d-21,1962 d-22$ (2013); see Hinkle, supra note 15, at 312-14.

253. 42 U.S.C. $§ 1962 d-20(b)(2)(2013)$. 
basin without the consent of every Great Lakes governor. ${ }^{254}$ The statute also continued to prohibit all federal agencies from studying the possibility of diverting water out of the basin unless the study is approved by all of the Great Lakes governors. ${ }^{255}$ Congress also required a comprehensive study of the Great Lakes region in order to ensure the proper management and protection of the Lakes and related resources ${ }^{256}$ and required the Corps of Engineers to develop a plan supporting the restoration and management of the Great Lakes fisheries. ${ }^{257}$

After the 2001 amendments to the 1986 Act, Michigan reenacted its ban on out-of-basin withdrawals, making it permanent and applicable to all withdrawals except for those existing on September 30, 2005. ${ }^{258}$ Michigan created a complex regulatory process to control water withdrawals within the state likely to affect trout streams within the Great Lakes watershed (virtually the entire state) ${ }^{259}$ Permits are to be issued only if the diverted water will be returned within the sub-basin of origin, the withdrawal causes no "adverse resource impact," and the withdrawal is "reasonable" under Michigan's common law. ${ }^{260}$ "Adverse resource impact" is defined as a reduction in the flow of a stream so that it can no longer support "characteristic fish populations." ${ }^{\text {"261 }}$ Certain municipally owned public distribution systems are exempted from the requirements of the act. ${ }^{262} \mathrm{~A}$ provision defines the bottling of water in containers of less than 5.7 gallons as a "consumptive use" that is not subject to the regulatory scheme. ${ }^{263}$ Withdrawals of more than one hundred thousand gallons per day must be registered even if not required to have a permit. ${ }^{264}$

Michigan's statute left only Pennsylvania without any statute dealing directly with the withdrawal of waters from the Great Lakes. Pennsylvania's governor still has the power to veto a withdrawal in any other state under the federal act, just as governors of other states could veto an out-of-basin withdrawal in Pennsylvania. ${ }^{265}$ Perhaps Pennsylvania has

254. Id. $\S \S 1962 \mathrm{~d}-20(\mathrm{~b})(3), 1962 \mathrm{~d}-20(\mathrm{~d})$.

255. Id. $\S \S 1962 \mathrm{~d}-20(\mathrm{~b})(4), 1962 \mathrm{~d}-20(\mathrm{e})$.

256. Id. $\S 1962 \mathrm{~d}-21$.

257. Id. $\S 1962 \mathrm{~d}-22$.

258. Mich. COMP. LAWS $\S \S 324.32703,324.32704$ (2013).

259. Id. $\S \S 324.32721-324.32723$. Permits are required for withdrawals of more than two mgd (million gallons per day) from the Great Lakes themselves or their connecting waters, and for withdrawals of more than five mgd from other waters within the state. $I d$. $\S$ 324.32723.

260. Id. $\S \S 324.32723(6), 324.32723(8)$.

261. Id. § 324.32701(a).

262. Id. $\S 324.32723(10)$.

263. Id. $\S 324.32701(\mathrm{k})$; see also id. $\S 325.1017$. This serves to protect the bottled water industry in Michigan.

264. MiCH. COMP. LAWS $\S \S 324.32705,324.32706,324.32708$ (2013).

265. 42 U.S.C. $\S 1962 d-20$ (d) (2013). 
not adopted its own statute because it recognizes that state legislation is unnecessary after Congress acted or for other reasons.

These statutes have been invoked in only two cases. The first was Portage County Board of Commissioners v. City of Akron. ${ }^{266}$ The county claimed that the city violated Ohio law by not obtaining a state permit for a withdrawal within the Lake Erie drainage basin, ${ }^{267}$ as well as by making an unreasonable withdrawal of surface water and by causing pollution. The city sought to remove the suit to federal court, alleging a federal question because the state law was preempted by the $1986 \mathrm{Act}^{268}$ and the Boundary Waters Treaty of $1909 .^{269}$ Judge James Gwin held that neither the federal statute nor the treaty created private rights; therefore, the Ohio statute was not preempted and there was no federal question. ${ }^{270}$ In Little Traverse Bay Band of Odawa Indians v. Great Spring Waters of America, Inc., ${ }^{271}$ the Indians attempted to use the 1986 Act to block the bottling and export of groundwater from the Great Lakes watershed. They claimed that the aquifer supplied a spring that supported their fishing rights in Lake Michigan and certain of its tributaries, as guaranteed by a treaty signed in $1836 .{ }^{272}$ After extended analysis of the 1986 Act's legislative history, Judge Richard Enslen dismissed the suit on the grounds that it did not create a private right of action. ${ }^{273}$ The suit went forward in state court on claims of damage to the environment with some initial success only to have the water-law claims dismissed for lack of standing. ${ }^{274}$

\section{STATUTES IMPLEMENTING THE GREAT LAKES WATERSHED WATER RESOURCES COMPACT}

By the year 2000, the federal government and seven of the eight Great Lakes states had erected a superstructure of laws that precluded the export of water from the Lakes. In addition to the possible vetoes by governors of the Great Lakes states (and of no other states) under the 1986 Act and the state statutes, the Army Corps of Engineers also held a veto over any withdrawal that could threaten the navigable capacity of any waterway

266. 12 F. Supp. $2 d 693$ (N.D. Ohio 1998).

267. Id. at 696 .

268. 42 U.S.C. $\S 1962 d-20$ (2013).

269. Treaty Relating to Boundary Waters Between the United States and Canada, U.S.U.K. Jan. 11, 1909, 36 Stat. 2448, TS No. 5481.

270. See Portage Cnty. Bd. of Comm'rs v. City of Akron, 12 F. Supp. 2d at 699-701.

271. Little Traverse Bay Band of Odawa Indians v. Great Spring Waters of America, Inc., 203 F. Supp. 2d 853 (W.D. Mich. 2002). For critiques of this decision, see Glass, supra note 231; Hinkle, supra note 15, at 315-19.

272. See Little Traverse Bay Band of Odawa Indians, 203 F. Supp. $2 d$ at 854.

273. See id. at $860-65$.

274. Michigan Citizens for Water Conserv. v. Nestlé Waters N. Am., Inc., 709 N.W.2d

174 (Mich. Ct. App. 2005), rev'd on other grounds, 737 N.W.2d 447 (Mich. 2007). 
within the watershed. ${ }^{275}$ This complex superstructure overrode the traditional roles and rights of the states. Indiana illustrates the problem this presents. The divide between the Great Lakes watershed and the Mississippi Valley lies just south of Lake Michigan in Indiana and Illinois. Because of the legal superstructure, Indiana could not take water from Lake Michigan or any stream draining into Lake Michigan for use in communities in the northern part of the state, if it were just across that divide, without the consent of the governors of every other Great Lakes state. ${ }^{276}$ In fact, the governor of Michigan vetoed precisely such a withdrawal for Lowell, Indiana, in 1992 - a town located in Lake County about five miles from the watershed divide. ${ }^{277}$ In contrast, the governor of Michigan did not veto a proposed withdrawal by Akron, Ohio in 1998 but only after the city agreed to bear the considerable expense of returning an equal amount of water to the source stream. ${ }^{278}$ Thus, while the legal superstructure protected Great Lakes states from threatened large-scale withdrawals for uses far removed from the watershed, it also prevented the states from taking small steps to manage their own needs without having to enter into serious (and sometimes impossible) negotiations with other watershed states.

This legal superstructure, however, was not as strong as it appeared. Congress could, at any time, repeal the 1986 Act. That could happen if the Congressional delegations of a sufficient number of dry states were to get together to vote themselves access to the water of the Lakes, or even if the other Great Lakes states were to tire of the Michigan veto. ${ }^{279}$ If the federal statute were repealed, any Great Lakes state could decide to divert "its" surplus water for an out-of-basin withdrawal (within or outside the state) despite efforts by other states to block it. A state opposed to another state's project could invoke original jurisdiction before the Supreme Court, but the opposing states are unlikely to obtain anything better than an equitable apportionment of the Lakes, something that the Supreme Court thus far has been unwilling to do. ${ }^{280}$ An equitable apportionment could result in vast

275. 33 U.S.C. $\S 1$. It would take a truly massive withdrawal to threaten the navigability of the Great Lakes, although the Corps did see that as a risk in the Chicago water withdrawals from Lake Michigan. See Sanitary Dist. v. United States, 266 U.S. 405 (1925).

276. Injerd, supra note 235.

277. George William Sherk, Resolving Interstate Water Conflicts in the Eastern United States: The Re-Emergence of the Federal-Interstate Compact, 30 WATER RESOURCES BULL. 397 (1994). Lake County takes its name from Lake Michigan.

278. See CITY OF AKRON WATER SYSTEM, supra note 235.

279. The problems of a state like Indiana remain today, despite (or perhaps because of) the newly adopted interstate compact. See Jeff Long, Lake County Towns Thirsty for Lake Water, CHI. Trib., Jan. 14, 2010, at 1; see also John Flesher, Debate Tests Great Lakes Compact: Communities Fear Losing Access to Water Supply, ST. PAUl PIONEer Press, Apr. 8, 2007, at B3; but see Richard Smardon, Great Lakes Compact Makes Sure NY Takes Care of Its Precious Water, Post STANDARD (Syracuse, NY), Aug. 28, 2011 , at El.

280. See generally Wisconsin v. Illinois, 449 U.S. 48 (1980); Wisconsin v. Illinois, 388 
amounts of water being diverted out of the watershed and probably would involve the participating states in litigation more protracted than even Charles Dickens could have imagined. ${ }^{281}$ A state across which the withdrawal would need to pass could block the project by simply denying the project eminent domain powers within its borders, thus barring the project from acquiring the necessary rights of way ${ }^{282}$-if the federal government does not become involved. ${ }^{283}$

The Great Lakes states thus were not satisfied with the situation created by the 1986 Act nor with the possibility of an original jurisdiction suit. They therefore negotiated a new compact and agreement for the Great Lakes without explicitly replacing the 1986 Act. $^{284}$ Whether the new arrangements actually will improve the cooperative or collective management of the Lakes, or even whether they will actually prevent exports of water out of the basin, is not entirely clear. ${ }^{285}$ Despite misgivings, all eight states enacted the compact and Congress gave its consent; the compact entered into effect in $2008{ }^{286}$ With some controversy, particularly in Ohio, ${ }^{287}$ the states enacted legislation to implement the compact.

U.S. 426 (1967); Wisconsin v. Illinois, 289 U.S. 395 (1933); Wisconsin v. Illinois, 281 U.S. 696 (1930); Wisconsin v. Illinois, 278 U.S. 367 (1929); New York v. Illinois, 274 U.S. 488, 489 (1927); Sanitary Dist. v. United States, 266 U.S. 405 (1925); see also Brad A. Everhardt, Great Lakes Water Resources: Planning for the Nation's Future, 3 TOL. J. GREAT LAKES L. SCI. \& POL'Y 90 (2001).

281. See generally Dellapenna, supra note 2, at 881-91.

282. Cf. Energy Transp. Sys. v. Union Pac. RR, 606 F.2d 934 (10th Cir. 1979); William Weber, Note, Coal Slurry Pipelines Are Ready, Willing, and Unable to Get There, 11 ST. MARY's L.J. 765, 767 (1980).

283. See Robert W. Tubbs, Comment, Great Lakes Water Withdrawal: Federal Authority over Great Lakes Water, 3 DET. CoLL. L. REV. 919 (1983).

284. Compact, supra note 16; Agreement, supra note 16.

285. See Jessica A. Bielecki, Managing Resources with Interstate Compacts: A Perspective from the Great Lakes, 14 BUFF. ENVTL. L.J. 173, 199 (2007); Dellapenna, supra note 233; Bridget Donegan, Comment, The Great Lakes Compact and the Public Trust Doctrine: Beyond Michigan and Wisconsin Common Law, 24 J. ENVTL. L. \& LiTIG. 455, 476, 483-84 (2009); Noah D. Hall \& Brett B. Stuntz, Climate Change and Great Lakes Water Resources: Avoiding Future Conflicts with Conservation, 31 HAMLINE L. REv. 639, 670 (2008); James M. Olson, Navigating the Great Lakes Compact: Public Trust, International Trade Agreements, MicH. ST. L. REv. 1103, 1127-1137 (2006); Austin J. Parrish, Mixed Blessings: The Great Lakes Compact and Agreement, the IJC, and International Dispute Resolution, MicH. ST. L. REv. 1299, 1318-1319 (2006); Lauren Petrash, Note, Great Lakes, Weak Policy: The Great Lakes-St. Lawrence River Basin Sustainable Water Resources Compact and Non-Regulation of the "Water Products" Industry, 39 U. MiAMI INTER-AM. L. REv. 145, 158-167 (2007); Brian Pokladowski, The Effect of the Great Lakes Compact on the Water Resources of Michigan, 11 J.L. IN Soc'Y 110 (2010); Mark A. Squillace, Rethinking the Great Lakes Compact, 2006 MiCH. ST. L. REv. 1347; Nicholas T. Stack, Note, The Great Lakes Compact and an Ohio Constitutional Amendment: Local Protectionism and Regional Cooperation, 37 B.C. ENVTL. AfF. L. REV. 493 (2010).

286. Act of October 3, 2008, Pub. L. No. 110-342, 122 Stat. 3740, $\S \S 4.8-4.9,4.11$.

287. See, e.g., Alan Johnson, Controversial Legislation: Lake Erie Water-Use Bill Nears Vote in Full House, Columbus (OH) DISPATCH, Apr. 25, 2012, at 1B; Alan Johnson, Ex- 
The implementation statutes in six states fall into one of two simple forms. One form incorporates the compact by reference and directs relevant state agencies to implement it. ${ }^{288}$ The second form copies the terms of the compact into the statute. ${ }^{289}$ Neither of these forms is intellectually challenging beyond understanding the compact itself. Pennsylvania did enact certain specific procedural requirements into its implementation statute without restating the compact's substantive requirements. ${ }^{290}$ In this setting, Michigan and Ohio are the outliers.

In anticipation of the then pending Great Lakes-St. Lawrence Watershed Water Resources Compact, ${ }^{291}$ Michigan reenacted its statute limiting withdrawals from the Great Lakes in $2005 .{ }^{292}$ Because the statute was already geared to what a few years later became the compact, few amendments were necessary when the legislature revisited the statute in $2008{ }^{293}$ The Michigan statute continues to prohibit all withdrawals from the Great Lakes for use in another watershed. ${ }^{294}$ This remains the only statute that flatly prohibits the export of water from the Lakes, although the statute does provide that in the event the prohibition proves invalid, withdrawals for use in another watershed must be "authorized by law." provision established a procedure for the governor to solicit public comments on whether to approve a withdrawal of water from the Lakes in another state for use out of the watershed, ${ }^{296}$ arguably weakening the stance as originally enacted in 1985 and carried forward in 2005. The amended statute also added a provision for new "assessment tools" to review proposed withdrawals and to monitor actual withdrawals. ${ }^{297}$ Otherwise the statute adopted the standards of the compact to govern withdrawals in Michigan, ${ }^{298}$ while adding a disclaimer of any intent to change common law

Gov. Taft Joins Opposition to Lake Erie Bill, ColumBus (OH) DisPATCH, June 24, 2011, at 4B; Alan Johnson, Revised Great Lakes Bill Critics: Lake Erie Plan Endangers Tributaries, Columbus (OH) Dispatch, Apr. 13, 2012, at 1B; see generally Stack, supra note 295 at 511.

288. See 45 Ill. CoMp. STAT. $\S \S 147 / 1,147 / 5$ (enacted 2007); MINN. STAT. $\S 103 G .801$ (enacted 2007); N.Y. ENVTL. CONSERV. CODE $§ 15-0505$ (6) (amended 2011); 32 PA. STAT. $§$ 817.22 (enacted 2008).

289. See IND. CODE §§ 14-25-15-1-14-25-15-13 (enacted 2008, as amended 2010); WIS. STAT. $\S \S 281.343-281.35$ (enacted 2008, as amended 2009, 2011).

290. 32 PA. STAT. $\S \S 817.21-821.30$ (effective July 4, 2008).

291. Compact, supra note 16.

292. Mich. COMP. LAWS $\S \S 324.32701-324.32723$ (2005); see the text supra at notes 226-30.

293. MiCH. COMP. LAWS $\S \S 324.32701-324.32723$ (amended 2008).

294. Id. $\S 324.32703$. The statute uses the term "diversion" instead of "withdrawal," defining "diversion" as a withdrawal for use in another watershed. Id. § 324.32701 (p). The statute exempts "diversions" in existence in 1985. Id. $\$ 324.32704$.

295. Id. $\S 324.32703 \mathrm{a}$.

296. Id. § 324.32704a.

297. Id. $\S \S 324.32706 \mathrm{a}, 324.32706 \mathrm{e}$.

298. Id. § 324.32730 . 
(riparian) water rights in the state. ${ }^{299}$

In Ohio, resistance in the legislature was particularly intense, centering on a claim that the compact would interfere with, or even abolish, private property rights in water. ${ }^{300}$ State Senator Ted Grendell argued that the compact would require Ohio to extend the public trust to groundwater and to non-navigable surface waters. ${ }^{301}$ The objections were overcome only by legislators agreeing to a referendum to confirm riparian rights in surface waters and the right of reasonable use in groundwater as constitutionally protected property rights. ${ }^{302}$ What remained unexplained then, and still is not explained now, is how the amendment changes anything. How much compensation is due for taking property if a right to use water could end tomorrow because the use is no longer reasonable? ${ }^{303}$ What sort of property right is it if a judge can decide that someone else has a more "reasonable" use of the water than the existing use $?^{304}$

Even before the amendment to the Ohio constitution was voted on, the legislature enacted new provisions for the "Lake Erie basin" that simply enacted verbatim the terms of the compact. ${ }^{305}$ The new legislation authorizes the governor to "administer" the compact, ${ }^{306}$ while authorizing the Chief of the Division of Soils and Water Resources to implement the compact. $^{307}$ It also requires legislative approval for any vote by the governor as the state's representative to the compact if the vote would change the legal standards under the compact. ${ }^{308}$ Like Michigan (and the compact), the Ohio legislation exempts bottled water in containers of less

299. Id. $\S 324.32728$.

300. Stack, supra note 295 , at $495-96$.

301. Id. at 516 .

302. Id. The amendment to the state constitution passed with an overwhelming majority and became: Оніо ConST. art. 1, § 19b(D) (adopted 2008); see Stack, supra note 295, at 51011.

303. See, e.g., Harris v. Brooks, 283 S.W.2d 129 (Ark. 1955); see generally Dellapenna, supra note 12; Joseph W. Dellapenna, The Reasonable Use Rule, in 2 WATERS AND WATER RIGHTS, supra note 12 , ch. 22 . Nick Stack reads the Ohio precedents as creating an absolute right to withdraw groundwater "so long as [the landowner] can put it to beneficial use." Stack, supra note 295, at 509. This seriously misreads the precedents. Ohio's Supreme Court assumes non-liability only so long as there is no showing that a use is unreasonable, either from causing unreasonable harm to another groundwater user or from exceeding a proprietor's reasonable share. McNamara v. Rittman, 838 N.E.2d 640, 643-44 (Ohio 2005); Cline v. American Aggregates Corp., 474 N.E.2d 324, 327 (Ohio 1984).

304. See Dellapenna, supra note $12, \S 7.04$ (b).

305. ОH. REv. CODE $\S \S 1522.01-1522.21$ (enacted 2008, as amended to 2012). See text supra at notes $284-85$.

306. OH. REv. CODE $\S 1522.02$.

307. Id. $\S 1522.03$. Other state agencies are authorized to cooperate with the compact authorities. $I d$. $\S 1522.05$.

308. Id. § 1522.04 . 
than 5.7 gallons from regulation. ${ }^{309}$ The legislation then creates, in considerable detail, a permitting process modeled on the compact for water uses within the state ${ }^{310}$ while disclaiming any effect on common law water rights. ${ }^{311}$ Some observers have concluded that this Ohio statute is the weakest in the basin, in large part because it was amended in 2012 to require permits only for withdrawals of more than $2.5 \mathrm{mgd} .^{312}$ Despite the criticism, $2.5 \mathrm{mgd}$ is not so different from the thresholds established by the implementation statute in other states.

In all but two states, the laws enacted before the compact was negotiated remain on the books. ${ }^{313}$ It is unclear whether these statutes remain as separate, additional standards with which compliance is necessary. The two exceptions are Michigan, in which the measures enacted to implement the compact took the form of amendments to the pre-compact statute, ${ }^{314}$ and Pennsylvania, which alone of the Great Lakes states had not enacted a statute to regulate or prohibit the export of water from the Great Lakes watershed before the compact was negotiated.

\section{CONCLUSIONS}

Over the past thirty years, the eight Great Lake states, the Canadian provinces of Ontario and Québec, and the two federal governments have created a complex legal superstructure that effectively precludes the export of water from the Great Lakes even to nearby areas within the Great Lakes states that lie outside the Great Lakes watershed. While the existing legal superstructure is impressive and currently highly effective, it is also fragile. In the face of increasing scarcity of unclaimed water across the globe as well as within North America, pressure will build to exploit the Lakes for uses outside their watershed. ${ }^{315}$ If precipitation changes from global climate disruption are even half as bad as current predictions, ${ }^{316}$ the approximately 4 percent of the global population that lives within the Great Lakes watershed cannot expect to continue to monopolize the Lakes' waters (21

309. Id. § 1522.06 .

310. Id. $\S \S 1522.10-1522.21$.

311. Id. § 1522.08 .

312. Id. $\S 1522.12$; see also $\S 1501.33$ (requiring permits for withdrawals by public water systems of more than two mgd). On the criticism as the "weakest link," see, e.g., Spencer Hunt, Lake Erie Water Lenient Limits Worry Critics, Columbus (OH) DiSPATCH, Nov. 27 , 2012 , at $5 \mathrm{~A}$.

313. See Part IV, supra.

314. See the text supra at notes $241-46$.

315. See Dellapenna, supra note 12, at 790-94.

316. See National Climate Assessment and Development advisory Committee, DRAFT Climate ASSESSMENT REPORT 107-66, 387-418 (2013), archived at http://perma.cc/03ojFPUNXNT. 
percent of the world's available fresh water supply ${ }^{317}$ ).

Someday a decision probably will be made to export water from the Great Lakes to distant regions. For example, the Ogallala Aquifer continues to be in crisis, a crisis exacerbated by the Great Drought of $2012 .^{318}$ It would not be a surprise if officials in the states overlying the aquifer began to look again to the Lakes for water. ${ }^{319}$ Already the compact region has accommodated the possibility of exporting water from the watershed to water users located within "straddling communities" and "straddling counties"-locations the legal boundaries of which lie partly within the watershed and partly without. ${ }^{320}$ Even continuing vigilance by the people resident within the watershed of the Great Lakes and St. Lawrence River are not likely to prevent exports to users at ever greater distances.

When or if a decision were to be made to allow at least limited exports of water from the Great Lakes watershed, all that would be necessary would be for Congress to repeal the $1986 \mathrm{Act}^{321}$ and the Great Lakes-St. Lawrence Water Resources Compact. ${ }^{322}$ Whatever Congress might enact in their place would be the supreme law of the land and would preempt any inconsistent state law. ${ }^{323}$ Finally, lurking in the background is the possibility that the legal superstructure, with its near complete ban of the export of water out of the Great Lakes to a nation other than Canada or the United States, violates the North American Free Trade Agreement (NAFTA) or the rules of the World Trade Organization (WTO). ${ }^{324}$

317. US EPA, Great Lakes: Basic Information, supra note 1.

318. See Mark Peters, Farmers Watching Their Water Use, WALL ST. J., Oct. 29, 2012, at A9.

319. For earlier proposals along these lines, see the authorities collected supra at note 14.

320. Compact, supra note 16, art. 1.2; see also Sarah E. Sharp, Interpreting Water Conservation Standards in Waukesha, Wisconsin: A Local Internalization of International Norms?, 16 U. DENV. WATER L. REV. 113 (2012).

321. 42 U.S.C. § 1962d-20d(c) (1994).

322. Great Lakes Watershed Water Resources Compact, supra note 16.

323. U.S. CONST. art. VI, cl. 2; see also First Iowa Hydro-Electric Coop. v. FPC, 328 U.S. 152 (1946).

324. See Christine Elwell, NAFTA Effects on Water: Testing for NAFTA Effects in the Great Lakes Basin, 3 TOL. J. GREAT LAKES L. SCI. \& POL'Y 151 (2001); Margrethe Krontoft \& William Testa, NAFTA and the Great Lakes: How Can We Achieve Both Economic and Environmental Sustainability?, 4 TOL. J. GREAT LAKES L. SCI. \& POL'Y 323 (2002); James M. Olson, Navigating the Great Lakes Compact: Public Trust, International Trade Agreements, 2006 Mich. ST. L. REV. 1103, 1122-26; A. Dan Tarlock, The Strange Career of the Dormant Commerce Clause and International Trade in the Great Lakes Anti-Withdrawal Regime, 2006 Mich. ST. L. REV. 1375; Marcia Valiente, Harmonization of Great Lakes Water Management in the Shadow of NAFTA, 81 U. DET. MERCY L. REV. 525 (2004). 